\title{
Stable isotope analyses revealed the influence of foraging habitat on mercury accumulation in tropical coastal marine fish
}

\author{
Le Croizier Gaël ${ }^{1,}{ }^{\text {, }}$, Schaal Gauthier ${ }^{1}$, Point David ${ }^{2}$, Le Loc'h François ${ }^{1}$, Machu Eric ${ }^{3,4}$, \\ Fall Massal $^{4,5}$, Munaron Jean-Marie ${ }^{1}$, Boyé Aurélien ${ }^{1}$, Walter Pierre ${ }^{2}$, Laë Raymond ${ }^{1}$, \\ Tito De Morais Luis ${ }^{1}$
}

${ }^{1}$ Laboratoire des Sciences de l'Environnement Marin (LEMAR), UMR 6539 CNRS/UBO/IRD/IFREMER, BP 70, 29280 Plouzané, France

${ }^{2}$ UMR Géosciences Environnement Toulouse (GET), Observatoire Midi Pyrénées (OMP), 14 avenue Edouard Belin, 31400 Toulouse, France

${ }^{3}$ Laboratoire d'Océanographie Physique et Spatiale (LOPS), UMR 6523 CNRS/UBO/IRD/IFREMER

IUEM, 29280 Plouzané, France

${ }^{4}$ Laboratoire de Physique de l'Atmosphère et de l'Océan Siméon Fongang, Université Cheikh Anta DIOP de Dakar, Ecole Supérieure Polytechnique, BP 5085, Dakar Fann, Sénégal

${ }^{5}$ Centre de Recherches Océanographiques de Dakar-Thiaroye (CRODT/ISRA), BP 2241, Dakar, Sénégal

* Corresponding author : Gaël Le Croizier, email address : gael.lecroizier@hotmail.fr

\begin{abstract}
:
Bioaccumulation of toxic metal elements including mercury $(\mathrm{Hg})$ can be highly variable in marine fish species. Metal concentration is influenced by various species-specific physiological and ecological traits, including individual diet composition and foraging habitat. The impact of trophic ecology and habitat preference on $\mathrm{Hg}$ accumulation was analyzed through total $\mathrm{Hg}$ concentration and stable isotope ratios of carbon $(\delta 13 \mathrm{C})$ and nitrogen $(\delta 15 \mathrm{~N})$ analyses in the muscle of 132 fish belonging to 23 different species from the Senegalese coast (West Africa), where the marine ecosystem is submitted to nutrients inputs from various sources such as upwelling or rivers. Species-specific ecological traits were first investigated and results showed that vertical (i.e. water column distribution) and horizontal habitat (i.e. distance from the coast) led to differential $\mathrm{Hg}$ accumulation among species. Coastal and demersal fish were more contaminated than offshore and pelagic species. Individual characteristics therefore revealed an increase of $\mathrm{Hg}$ concentration in muscle that paralleled trophic level for some locations. Considering all individuals, the main carbon source was significantly correlated with $\mathrm{Hg}$ concentration, again revealing a higher accumulation for fish foraging in nearshore and benthic habitats. The large intraspecific variability observed in stable isotope signatures highlights the need to conduct ecotoxicological studies at the individual level to ensure a thorough understanding of mechanisms driving metal accumulation in marine fish. For individuals from a same species and site, $\mathrm{Hg}$ variation was mainly explained by fish length, in accordance with the bioaccumulation of $\mathrm{Hg}$ over time. Finally, $\mathrm{Hg}$ concentrations in fish muscle are discussed regarding their human health impact. No individual exceeded the current maximum acceptable limit for seafood consumption set by both the European Union and the Food and Agriculture Organization of the United Nations. However, overconsumption of
\end{abstract}


some coastal demersal species analyzed here could be of concern regarding human exposure to mercury.

\section{Graphical abstract}

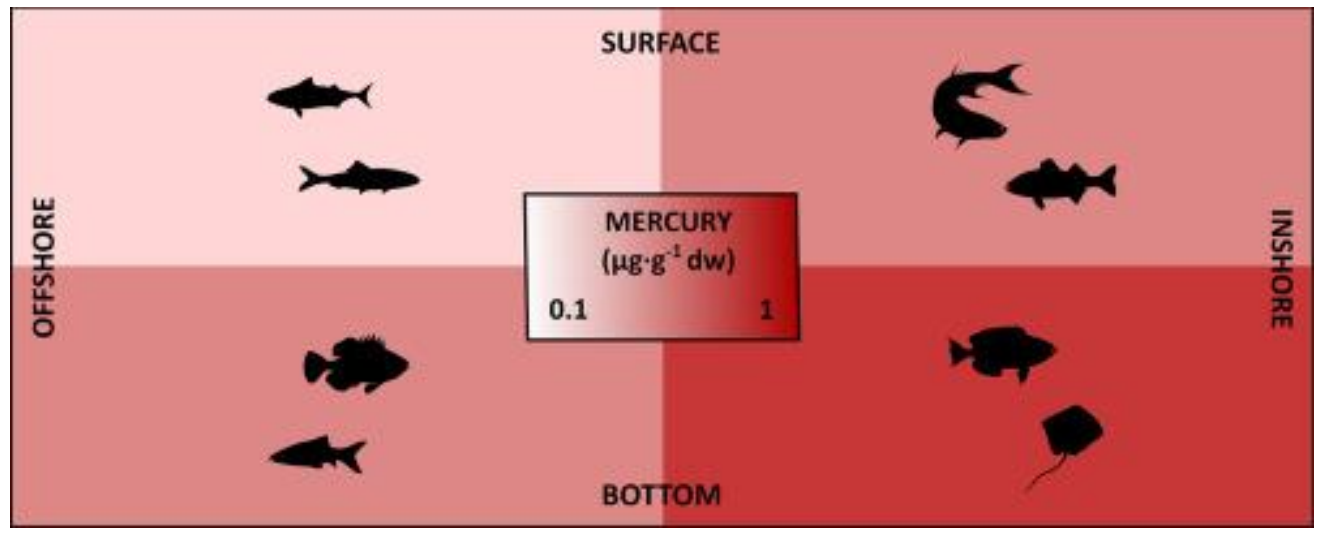

\section{Highlights}

$\mathrm{THg}, \delta^{13} \mathrm{C}, \delta^{15} \mathrm{~N}$ were determined in 132 marine fish from a tropical coastal region. $>$ Coastal and demersal species were more contaminated than oceanic and pelagic ones. SIA suggest that $\mathrm{Hg}$ exposure derived from bottom feeding and/or in estuarine waters. Conspecific fish fed on different coastal food webs and $\mathrm{Hg}$ increased with fish size. Hg levels in fish from Senegal were not of concern for human consumption.

Keywords: Methylmercury sources, Trophic ecology, Feeding habitat, Metal bioaccumulation, Chemical tracers, Isotopic niche 


\section{INTRODUCTION}

Coastal areas provide many ecosystem services such as fish production, ensuring the supply of marine products to local populations and supporting the economies of coastal countries, particularly through the export (Interwies and Görlitz, 2013). Among the many disturbances to which these ecosystems are subjected, mercury $(\mathrm{Hg})$ contamination is a major environmental concern, due to its deleterious effects on marine organisms and human health (Streets et al., 2011). Hg originates from both natural and anthropogenic processes, including geological weathering, gold mining, combustion and industrial discharges. Although $\mathrm{Hg}$ is volatile and can be transported through the atmosphere over long distance away from emission sources, coastal environments are particularly subjected to $\mathrm{Hg}$ exposure since they are located at the interface between three main Hg sources: atmosphere, rivers and ocean (Cossa et al., 1996).

After being released into seawater, $\mathrm{Hg}$ can be methylated by microorganisms such as sulfate and iron-reducing bacteria or methanogens (Correia and Guimarães, 2017; Gilmour et al., 2013; Paranjape and Hall, 2017; Podar et al., 2015) in coastal and shelf sediments as well as in sub-thermocline oceanic waters, where oxygen concentration is low and organic matter is intensively remineralized (Blum et al., 2013; Cossa et al., 2017; Fitzgerald et al., 2007). Once in the organic methylmercury form (MeHg), this metal is easily taken up by phytoplankton and biomagnifies along trophic chains. Biomagnification (i.e. increase in $\mathrm{MeHg}$ content with trophic level) is responsible for high $\mathrm{Hg}$ concentration in the tissues of top predators such as 
tunas and sharks (McKinney et al., 2016). As trophic level is closely correlated with nitrogen stable isotope ratios $\left(\delta^{15} \mathrm{~N}\right)$ (Post, 2002), this marker has been extensively used to explain quantities of Hg in biota (Kiszka et al., 2015; McMeans et al., 2010; Pethybridge et al., 2012). Species with similar trophic levels can, however, display different patterns of $\mathrm{Hg}$ accumulation (Bank et al., 2007; Le Croizier et al., 2016) and other factors have been linked to $\mathrm{Hg}$ concentrations. First, like other metal elements, $\mathrm{Hg}$ strongly binds to sulfhydryl groups of proteins in marine fish leading to a very slow excretion of the bioaccumulated $\mathrm{Hg}$ over time, particularly in muscle tissues (Kidd and Batchelar, 2011; Peng et al., 2016). As a consequence, $\mathrm{Hg}$ concentration has been extensively shown to increase with fish age, being positively correlated with size or weight (Bosch et al., 2016; Chouvelon et al., 2014; Pethybridge et al., 2010). Second, Hg concentrations in fish tissues are also known to increase with depth of occurrence in the water column, corresponding to concentrations of dissolved organic mercury in seawater and/or proximity to sediments (Chouvelon et al., 2012; Choy et al., 2009). Third, ecosystem characteristics such as human activities, density and composition of phytoplankton communities can influence $\mathrm{Hg}$ bioaccumulation and subsequent biomagnification (Chen and Folt, 2005; Chouvelon et al., 2018; Condini et al., 2017; Heimbürger et al., 2010).

Finally, some studies focusing on $\mathrm{Hg}$ sources found differences in $\mathrm{Hg}$ concentrations between offshore and nearshore species or between pelagic and benthic species, depending on whether $\mathrm{Hg}$ methylation takes place in pelagic deep waters or in coastal sediments(Cresson et al., 2014; Sackett et al., 2015; Senn et al., 2010). Carbon stable isotope values $\left(\delta^{13} \mathrm{C}\right)$ have commonly been used to discriminate oceanic/pelagic from coastal/demersal habits in marine fish in order to investigate the role of foraging habitat in $\mathrm{Hg}$ bioaccumulation (Cresson et al., 2014; Goutte et al., 2015; Pethybridge et al., 2012; Signa et al., 2017). Coastal fish species have 
a wide range of prey and habitat use, however, which leads to large intraspecific variability in metal accumulation (Bird et al., 2018; Le Croizier et al., 2016; Sackett et al., 2015). It therefore seems essential to conduct ecotoxicological studies at the individual level to better determine the origin of the accumulated $\mathrm{Hg}$ in fish tissues.

In this context, the general goal of the present study was to investigate the trophic origin of mercury exposure to coastal fish from the Canary Current Large Marine Ecosystem (CCLME) in Western Africa. This ecosystem is of particular interest since it is one of the world's major cold-water upwelling currents and ranks first in the world in terms of primary productivity (Messié and Chavez, 2015). It supports one of the largest fisheries among African large marine ecosystems and provides food to local populations but also to foreign countries through the attribution of fishing licenses and export of marine products. This marine ecosystem is prone to metal contamination due to urban effluents and industrial activities (Auger et al., 2015; Diop et al., 2015) and $\mathrm{Hg}$ has been recently identified as one of the toxic elements reported at significant concentrations in sediments and marine organisms from this coastal zone (Bodin et al., 2013; Diop and Amara, 2016; Net et al., 2015). Hence, as Hg can cause serious pathologies including neurological impairments (Bosch et al., 2016) and fish consumption represents the major pathway for human exposure to $\mathrm{Hg}$ (Driscoll et al., 2013), a proper evaluation of $\mathrm{Hg}$ sources and concentrations was needed in fish from this area.

To fulfill this objective, total mercury concentrations were determined in a wide range of fish belonging to 23 different species. Total mercury was used as a proxy of methylmercury, since MeHg generally represents more than $80 \%$ of the total mercury found in fish muscle, regardless of their ecological characteristics (Andersen and Depledge, 1997; Bloom, 1992; Magalhães et al., 2007; Storelli et al., 2003). The main origin for $\mathrm{Hg}$ contamination was investigated through the reported habitat distribution of the species. This method allowed to 
discriminate $\mathrm{Hg}$ exposure between oceanic versus coastal and pelagic versus demersal sources, but did not take into account the individual specialization in terms of foraging habitat. Thus, a second complementary approach was undertaken using stable isotope analyses, particularly $\delta^{13} \mathrm{C}$ that gives information at the individual level but only discriminate between oceanic/pelagic versus coastal/demersal source. Finally, the potential health impact associated with fish consumption in the area was discussed in relation to the tolerable $\mathrm{Hg}$ intake limit established by the European Union and the Food and Agriculture Organization of the United Nations.

\section{MATERIALS AND METHODS}

\section{Sampling}

A total of 132 fish belonging to 23 different species were sampled at four different locations along the Senegalese coast in West Africa (from north to south): Saint-Louis, Dakar, Saloum and Casamance (Figure 1). Saint-Louis, Saloum and Casamance are located off estuaries, while Dakar is located along a rocky coast. Samples used in this study were collected during a scientific cruise (doi, 10.17600/14001400) of the BMBF - IRD AWA Project "Ecosystem Approach to the management of fisheries and the marine environment in West African waters" (01DG12073E) in March 2014 aboard the RV Thalassa. Fish were caught with a bottom trawl net, packed in plastic bags and frozen on board at $-20^{\circ} \mathrm{C}$ until further analyses.

\section{Chemical analyses}

Once at the laboratory, the fish were weighed (wet weight) and measured (total length) (Table 1). They were then dissected with ceramic tools to avoid metal contamination, and a piece of 
dorsal muscle (a standardized cut from just behind the head) was collected. Muscle samples for the analysis of stable isotopes were freeze-dried and ground into a fine homogeneous powder. Approximately $350 \mu \mathrm{g}$ of powder was then weighed in tin capsules for isotopic analysis. The samples were analyzed by continuous flow on a Thermo Scientific Flash EA 2000 elemental analyzer coupled to a Delta V Plus mass spectrometer at the Pôle de Spectrométrie Océan (Plouzané, France). Results are expressed in standard $\delta$ notation based on international standards (Vienna Pee Dee Belemnite for $\delta^{13} \mathrm{C}$ and atmospheric nitrogen for $\delta^{15} \mathrm{~N}$ ) following the equation $\delta^{13} \mathrm{C}$ or $\delta^{15} \mathrm{~N}=[($ Rsample/Rstandard $)-1] \times 10^{3}$ (in \%o), where $\mathrm{R}$ is ${ }^{13} \mathrm{C} /{ }^{12} \mathrm{C}$ or ${ }^{15} \mathrm{~N} /{ }^{14} \mathrm{~N}$. Samples were not delipidated because muscle generally contains a lower level of lipids than other organs in fish (Njinkoué et al., 2002). However, since lipid content can impact $\delta^{13} \mathrm{C}, \mathrm{C} / \mathrm{N}$ ratios were measured. These values exceeded 3.5 for a few samples (i.e. 18 individuals among 132 in total, see Supplementary Material), so a mathematical normalization was applied to all samples, following the equation $\delta^{13} \mathrm{C}$ normalized $=\delta^{13} \mathrm{C}$ untreated $-3.32+$ $0.99 \bullet \mathrm{C} / \mathrm{N}$ (Le Croizier et al., 2016; Post et al., 2007). International isotopic standards of known $\delta^{15} \mathrm{~N}$ and $\delta^{13} \mathrm{C}$ were used: IAEA-600 caffeine, IAEA-CH-6 sucrose, IAEA-N-1 and IAEA-N-2 ammonium sulfate. The certified values of the standards were reproduced within the confidence limits: IAEA-600 (certified values: $-27.77 \pm 0.04 \%$ ofor $\delta^{13} \mathrm{C}$ and $1.00 \pm 0.20 \%$ ofor $\delta^{15} \mathrm{~N}$; measured value: $-27.79 \pm 0.10 \%$ for $\delta^{13} \mathrm{C}$ and $1.09 \pm 0.06 \%$ for $\delta^{15} \mathrm{~N}$ ), IAEA-CH-6 (certified values: $-10.45 \pm 0.08 \%$ for $\delta^{13} \mathrm{C}$; measured value: $-10.43 \pm 0.08 \%$ for $\delta^{13} \mathrm{C}$ ), IAEA$\mathrm{N}-1$ (certified values: $0.4 \pm 0.2 \%$ for $\delta^{15} \mathrm{~N}$; measured value: $0.45 \pm 0.10 \%$ for $\delta^{15} \mathrm{~N}$ ) and IAEA$\mathrm{N}-2$ (certified values: $20.3 \pm 0.2 \%$ for $\delta^{15} \mathrm{~N}$; measured value: $20.24 \pm 0.12 \%$ ofor $\delta^{15} \mathrm{~N}$ ). A home standard (Thermo acetanilide) was analyzed every 6 samples for experimental precision (based on the standard deviation of the replicates of the internal standard) and indicated an analytical precision of $\pm 0.12 \%$ for $\delta^{13} \mathrm{C}$ and $\pm 0.06 \%$ for $\delta^{15} \mathrm{~N}$. 
Total $\mathrm{Hg}$ determination was carried out on an aliquot section (around $50 \mathrm{mg}$ ) of the dried muscle by combustion, gold trapping and atomic absorption spectrophotometry detection using a DMA80 analyzer (Milestone, USA). Mercury concentrations in the muscle samples are expressed on a dry weight $\left(\mu \mathrm{g} \cdot \mathrm{g}^{-1} \mathrm{dw}\right)$, and wet weight $\left(\mu \mathrm{g} \cdot \mathrm{g}^{-1} \mathrm{ww}\right)$ basis when needed (i.e. for comparison with current maximum acceptable limits for seafood consumption that are expressed on a wet weight basis), applying a moisture correction factor determined for each individual sample by using the mass ratio before and after freeze drying. The accuracy and reproducibility of the method were established using two freeze-dried certified biological materials; a tuna fish flesh homogenate reference material (IAEA 436, IRMM) and a Lobster Hepatopancreas reference material (TORT3, NRCC). The certified values for IAEA 436 (4.19 \pm $0.36 \mu \mathrm{g} \cdot \mathrm{g}-1 \mathrm{dw}$ ) were reproduced (measured value: $4.28 \pm 0.14 \mu \mathrm{g} \cdot \mathrm{g}-1 \mathrm{dw}$ ) within the confidence limits. The certified values for TORT3 $(0.292 \pm 0.022 \mu \mathrm{g} \cdot \mathrm{g}-1 \mathrm{dw})$ were also reproduced (measured value: $0.280 \pm 0.005 \mu \mathrm{g} \cdot \mathrm{g}-1 \mathrm{dw}$ ) within the confidence limits. Repeatability varied from 1.9 to $6.7 \%$ depending on the concentration of the sample and its heterogeneity. The detection limit was $0.005 \mu \mathrm{g} \cdot \mathrm{g}-1 \mathrm{dw}$.

\section{Ecological data of species}

The ecological distribution of each species was defined on both the "horizontal" axis (i.e. the offshore-inshore gradient) and the "vertical" axis (i.e. water column occupation). On the horizontal axis, "Offshore" includes bathydemersal and oceanodromous species while "Inshore" includes coastal, brackish and estuarine species. On the vertical axis, the different fish species were grouped according to their known habitat (i.e. pelagic, benthopelagic and demersal). For both axes, species were classified following general published literature for most species in the area (Caverivière, 1993; Diouf, 1996; Froese and Pauly, 2018; Séret, 2011) 
and specific studies for fish species in particular: Boops boops (Derbal and Hichem Kara, 2008), Caranx rhonchus (Boëly et al., 1973; Sley et al., 2008), Chloroscombrus chrysurus and Galeoides decadactylus (Faye et al., 2011), Diplodus bellottii (Horta et al., 2004), Scomber japonicus (Castro, 1993), Sphyraena guachancho (Akadje et al., 2013), Trachurus trecae (Boëly et al., 1973).

\section{Statistical analyses}

All data tested statistically were first checked for normality (Shapiro-Wilks tests) (Shapiro and Wilk, 1965) and homogeneity of variances (Bartlett tests) (Bartlett, 1937). When these conditions were met, raw data (or log-transformed data, if necessary) were used and one-way ANOVAs, followed by Tukey's HSD tests, were performed to test for differences between groups (i.e. Hg variation between sites or groups of species based on their ecological distribution, stable isotope variations between groups of individuals based on their isotopic values). Otherwise, non-parametric analogues were used, i.e. Kruskal-Wallis tests (KW), followed by Conover-Iman multiple comparison tests with Bonferroni's adjustment when more than two groups were compared (Conover and Iman, 1979), to test for differences in $\delta^{15} \mathrm{~N}$ values between sites or $\mathrm{Hg}$ concentration between groups of individuals based on their $\delta^{13} \mathrm{C}$ values.

To assess the relationships between individual $\mathrm{Hg}$ bioaccumulation and feeding habitat and trophic level, $\mathrm{Hg}$ concentrations were modeled using linear regressions with isotopic values $\left(\delta^{13} \mathrm{C}, \delta^{15} \mathrm{~N}\right)$ as explanatory variables. To evaluate the intraspecific variability in foraging habitat and its effect on mercury concentration, individual fish were classified in two groups based on $\delta^{13} \mathrm{C}$ values, using a K-means cluster analysis (Hartigan and Wong, 1979). This clustering method delineates groups in the data by minimizing the sum of the within-groups 
sums of squared-distances, based on Euclidean distance. The number of groups for the partition was defined using the Caliński-Harabasz criterion (Caliński and Harabasz, 1974). The influence of the horizontal and vertical habitat at the species level as well as individual characteristics (i.e. $\delta^{13} \mathrm{C}, \delta^{15} \mathrm{~N}$, length and weight) on muscle $\mathrm{Hg}$ concentrations was tested using linear mixed models (LMMs) with species and/or sampling site as a random effect on the whole data set ( $n=132)$, using the R package "Ime4" (Bates et al., 2014). The models were constructed with a gamma distribution and a log link function based on residual analysis (Zuur et al., 2009). To identify the most important factors explaining $\mathrm{Hg}$ concentrations, the different models were ranked based on Akaïke's Information Criteria adjusted for small sample sizes (AICc) and compared using $\triangle \mathrm{AICC}$ and Akaike weights $(\mathrm{w})$ using the R package "wiqid" (Meredith, 2017). Models with AICc values differing by less than two have a similar level of support in the data (Burnham and Anderson, 2002). To assess the explanative power of these models, marginal $R^{2}$ was obtained following Nakagawa Shinichi et al., 2012 using the $R$ package "r2glmm" (Jaeger, 2017).

All of the statistical analyses were performed using the open source software R (version 3.4.3, R Core Team, 2017).

\section{RESULTS AND DISCUSSION}

\section{$\mathrm{Hg}$ exposure under estuarine and upwelling influence}

Concerning $\mathrm{Hg}$ spatial variation, fish sampled off the Saloum estuary (all species combined: $\mathrm{n}$ $=44$ ) displayed higher Hg concentrations than those from Saint-Louis (all species combined: $\mathrm{n}$ $=24$ ) or Dakar (all species combined: $n=29$ ) (ANOVA followed by Tukey's HSD test; $p<0.01$ )

(Figure 2). This variation may be first related to the sampling of different species between 
sites. Indeed, the different sites showed very few common species (only Caranx rhonchus in Dakar and Casamance, Pseudupeneus prayensis in Dakar and Saloum, Trachurus trecae in Dakar and Saloum; Table 1). In addition, species-specific characteristics such as ingestion rate, assimilation efficiency, growth rate, organ distribution, subcellular handling and excretion rate, constitute physiological factors that influence $\mathrm{Hg}$ concentration in muscle tissue (Peng et al., 2016; Wang and Wang, 2018, 2015; Wang and Wong, 2003). This diversity of species may thus have participated to the $\mathrm{Hg}$ variation between locations. Other possible explanations relate to hydrodynamic processes. First, sources of $\mathrm{Hg}$ in coastal waters include inputs from upwellings, rivers, groundwater, atmospheric deposition and waste water point sources (Cossa et al., 2017). The river-watershed contributes greatly to $\mathrm{Hg}$ inputs to coastal waters (Balcom et al., 2015; Choe and Gill, 2003) and is estimated to be the highest total mercury source in ocean margins, mainly in association with organic particles (Cossa et al., 1996). The higher $\mathrm{Hg}$ contamination in fish from the Saloum station may thus be the result of their feeding in the estuarine zone that is influenced by riverine inputs, as suggested by the high $\delta^{15} \mathrm{~N}$ baseline. Moreover, the Saloum site is located near the mouth of the Gambia River, that is impacted by the use of $\mathrm{Hg}$ for gold amalgamation in small artisanal mining (Niane et al., 2015). It is thus hypothesized that the Gambia River estuary could be a source of anthropogenic $\mathrm{Hg}$ for fish feeding in this coastal area, including those sampled at the Saloum site. Second, $\mathrm{Hg}$ bioavailability depends largely on water column stratification as MeHg production peaks at the thermohalocline where density gradient is maximum and allows organic matter accumulation as well as the associated bacterial activity (Cossa et al., 2012). In areas under riverine influence such as estuaries, freshwater inputs might generate a thermohalocline near the surface, together with organic matter flocs that could enhance MeHg formation. This higher $\mathrm{Hg}$ bioavailability would thus be partially responsible for the higher $\mathrm{Hg}$ concentrations 
in fish from the Saloum region, that supposedly feed in the Saloum and Gambia river estuaries. Third, upwellings constitute a major $\mathrm{Hg}$ source from the ocean to the neritic zone. Indeed, MeHg is mainly formed near the shelf edge, where organic carbon degradation is intense. Upwelled waters from this depth can account for more than half of MeHg accumulated by fish in ocean margins (Cossa et al., 2017, 1996). In Senegal, upwelling occurs mainly in winter and is stronger from February to April. It produces a coastal jet confined nearshore that flows southward alongside the coast (Auger et al., 2015). Recently, coastal waters of southern Senegal were shown to originate from an upwelling area in the north (Ndoye et al., 2017). Because the fish were collected during the active upwelling season when the coastal current is the strongest, transport of MeHg by upwelled waters might contribute to the greater $\mathrm{Hg}$ concentrations at the most southern locations (i.e. Saloum and Casamance; Figure 2C). This pattern was also previously observed for other metals such as cadmium (Le Croizier et al., 2016).

\section{Influence of foraging habitat on $\mathrm{Hg}$ accumulation at the species level}

The different fish species were classified in two distinct groups according to horizontal distribution (i.e. the offshore-inshore gradient). "Offshore" includes bathydemersal and oceanodromous species while "Inshore" includes coastal, brackish and estuarine species. Hg concentration in the muscle was higher in inshore fish than in offshore ones (ANOVA; $p<$ 0.001) (Figure 3A), showing that proximity to the coast implies higher $\mathrm{Hg}$ exposure. In the present case study, the higher contamination of inshore species can first be explained by the estuarine influence that may bring substantial inorganic particulate $\mathrm{Hg}$ to the coastal marine environment where MeHg production occurs (Figure 4), as observed in other areas like the northern Gulf of Mexico and the Mediterranean Sea (Cossa and Coquery, 2005; Senn et al., 
2010). Then, this contamination pattern can also be explained by the higher methylation rate observed in coastal sediments subjected to significant inputs of organic material (OM) from catchment (Lambertsson and Nilsson, 2006; Merritt and Amirbahman, 2009). In a previous study, higher concentrations of $\mathrm{Hg}$ were found in coastal species from Senegal during the wet season (Diop and Amara, 2016), that increases runoff from land and rivers, compared to the dry season where the upwelling intensity is higher (Ndoye, 2016). This observation strengthens the hypothesis of the input of $\mathrm{Hg}$, and/or $\mathrm{OM}$ that enhances methylation, to the coastal environment by rivers rather than upwelling.

In order to investigate the influence of vertical distribution (i.e. water column occupation), the different fish species were grouped according to their known habitat (i.e. pelagic, benthopelagic and demersal). Hg concentration increased from the surface to the bottom, demersal species exhibiting higher $\mathrm{Hg}$ concentrations relative to pelagic fish, while benthopelagic species showed intermediate Hg values (ANOVA followed by Tukey's HSD test; $\mathrm{p}<0.01$ ) (Figure 3B). Trophic level is one of the main contributors to $\mathrm{Hg}$ variation when different fish species are compared (Kiszka et al., 2015; McMeans et al., 2010; Pethybridge et al., 2012). However, in the present study, TL derived from the literature (Table 1) did not significantly differ between groups: $T L$ pelagic $=3.8 ; \mathrm{TL}$ benthopelagic $=3.7 ; \mathrm{TL}$ demersal $=3.5$ (ANOVA; $p>0.5$ ). On the other hand, microbial MeHg production and subsequent mobilization from sediments is known to be a major source of $\mathrm{Hg}$ accumulation for coastal marine organisms including edible fish (Hammerschmidt and Fitzgerald, 2006), implying a higher Hg bioavailability for benthic organisms (Fitzgerald et al., 2007). Moreover, photodemethylation by ultraviolet radiation acts to remove $\mathrm{MeHg}$ from surface water and reduces $\mathrm{Hg}$ bioavailability for pelagic species that feed near the surface (Lehnherr et al., 2011) (Figure 4). In the absence of trophic level influence, these two mechanisms may explain the Hg gradient 
found along the water column distribution of the species sampled in the present study. These results are in accordance with a previous study on a wide range of species ( $n=120)$ from the Bay of Biscay (North-East Atlantic), in which pelagic organisms showed lower $\mathrm{Hg}$ concentrations than benthic and benthopelagic ones (Chouvelon et al., 2012). Moreover, in this previous study, water column distribution was the factor that contributed the most to explain the variability in muscle $\mathrm{Hg}$ concentrations, highlighting the importance of this parameter in understanding marine fish species exposure to $\mathrm{Hg}$.

\section{Influence of foraging habitat on $\mathrm{Hg}$ accumulation at the individual level}

$\mathrm{Hg}$ accumulation was previously shown to be linked to species-specific characteristics in the horizontal and vertical distribution (Figure 3). Some fish species can however display a high intraspecific variability in terms of diet composition and foraging habitat, which can be reflected in metal accumulation (Das et al., 2000; Le Croizier et al., 2016). Intraspecific variability in horizontal distribution can lead to differences in $\mathrm{Hg}$ accumulation in the dusty grouper Epinephelus marginatus from the Southern Brazilian coast, where individuals sampled in an estuarine zone were more contaminated than those from an offshore bank due to anthropogenic $\mathrm{Hg}$ discharges into the drainage basin of the estuary (Condini et al., 2017). Vertical distribution can also contribute to variation in $\mathrm{Hg}$ among individuals of the same species. It can occur through an ontogenetic shift in foraging habitat, as for the bluefish Pomatomus saltatrix, that presents higher $\mathrm{Hg}$ accumulation during its early life stage when feeding on benthic preys compared to feeding on pelagic preys in later years (Szczebak and Taylor, 2011). It can also result from depth of occurrence, as shown for the European hake Merluccius merluccius in the northwestern Mediterranean, where the $\mathrm{Hg}$ concentrations in muscle followed the MeHg distribution in the water column (Cossa et al., 2012). These authors 
concluded that Hg bioavailability was higher for hake inhabiting the continental slope than the continental shelf. Working at the species level might not, therefore, be the most relevant method to study metal bioaccumulation. Following this postulate, individual stable isotope values were used to investigate the role of trophic position and foraging habitat in $\mathrm{Hg}$ contamination, through $\delta^{15} \mathrm{~N}$ and $\delta^{13} \mathrm{C}$, respectively.

Numerous studies found that $\mathrm{Hg}$ concentrations in marine fish are mainly explained by $\delta^{15} \mathrm{~N}$, that is a proxy of trophic level (Sackett et al., 2015; Senn et al., 2010). MeHg is biomagnified (i.e. to increase with trophic level) within marine food webs (McMeans et al., 2010; Signa et al., 2017), making $\delta^{15} \mathrm{~N}$ a primary indicator for $\mathrm{Hg}$ accumulation. In the present study, $\delta^{15} \mathrm{~N}$ varied among locations (see Supplementary Material, Figure S1; KW followed by ConoverIman test, $\mathrm{p}<0.001$ ) suggesting differences in $\delta^{15} \mathrm{~N}$ baselines between ecosystems, so that the link between $\delta^{15} \mathrm{~N}$ and $\mathrm{Hg}$ was only investigated at the local level. $\mathrm{Hg}$ concentration in fish muscle was found to be positively correlated with $\delta^{15} \mathrm{~N}$ in Saint-Louis (Figure $5 \mathrm{~A}, p<0.001$ ) and Dakar (Figure 5B, $p<0.001$ ) while no correlation was observed in Saloum (Figure $5 C$ ) or Casamance (Figure 5D). In the first two sites, $\mathrm{Hg}$ accumulation followed trophic position, as frequently observed in fish communities. In Saloum and Casamance, the lack of observed biomagnification can be attributed to the limited $\delta^{15} \mathrm{~N}$ gradient within these fish communities compared to those from northern sites. Indeed, a previous study on bioaccumulation of other metal elements found three $\delta^{15} \mathrm{~N}$-based trophic levels in fish from Dakar, while those from Casamance displayed only two trophic levels (Le Croizier et al., 2016). These findings suggest that $\delta^{15} \mathrm{~N}$ would not be relevant to explain $\mathrm{Hg}$ accumulation variability among fish that were too close in trophic level. Furthermore, the northern ecosystems (i.e. Saint-Louis and Dakar) may support only one main nitrogen source of marine origin, while southern sites (i.e. Saloum and Casamance) may display two main nitrogen sources, one of marine origin and the other 
one of estuarine or upwelling origin. Multiple nitrogen sources may thus obscure the classical correlation between $\mathrm{Hg}$ and $\delta^{15} \mathrm{~N}$ in locations influenced by estuarine inputs. Because both vertical and horizontal distribution is reflected in $\delta^{13} \mathrm{C}$, this marker can give confusing information concerning water column distribution and proximity to the coast. However, it allows to globally discriminate pelagic/offshore from demersal/inshore habits of the fish. $\delta^{13} \mathrm{C}$ did not vary significantly with location in our study (ANOVA, $p>0.05$ ), but $\delta^{13} C$ values in fish from the Saloum station displayed a particular pattern. While low $\delta^{13} \mathrm{C}$ values are generally attributed to pelagic/offshore foraging habitats in marine food webs, organisms from areas exposed to terrestrial inputs like estuaries can be depleted in ${ }^{13} \mathrm{C}$ due to the lower $\delta^{13} \mathrm{C}$ of terrestrial particular organic matter (POM) compared with marine POM (Cresson et al., 2014; Darnaude, 2005). It can therefore lead to the observation of low $\delta^{13} \mathrm{C}$ in fish known to inhabit coastal benthic habitats. In fish sampled off the Saloum estuary, the three species displaying the lowest $\delta^{13} \mathrm{C}$ values were Chelidonichthys gabonensis, Pseudupeneus prayensis and Dentex canariensis $\left(\delta^{13} \mathrm{C}=-16.96 \pm 0.35 \%\right.$, $-16.93 \pm 0.55 \%$ and $-16.54 \pm 0.37 \%$, respectively $)$, all described as coastal and demersal species (Table 1). Furthermore, the Saloum estuary is subjected to terrestrial carbon sources, such as mangrove leaves, which lead to really low $\delta^{13} \mathrm{C}$ values for both particulate and sediment organic matter (i.e. around -25 \%) (Faye et al., 2011; Gning et al., 2010). These findings thus suggest that the low $\delta^{13} \mathrm{C}$ values observed in these three particular coastal/demersal species reflected the use of the estuarine habitat of Saloum and Gambia River rather than offshore/pelagic signatures (Figure 6A). In fish from this site, $\mathrm{Hg}$ concentrations increased for both the lowest $\delta^{13} \mathrm{C}$ (terrestrial influence) and the highest $\delta^{13} \mathrm{C}$ (inshore/demersal) $(\mathrm{p}<0.001)$, showing the higher $\mathrm{Hg}$ accumulation of individuals with estuarine foraging. Apart from the local trend off the Saloum estuary, as the $\delta^{13} \mathrm{C}$ pattern was similar between sites, the link between $\mathrm{Hg}$ and $\delta^{13} \mathrm{C}$ was investigated on all fish from the 
remaining locations together. A positive correlation was also found between individual $\mathrm{Hg}$ concentrations and $\delta^{13} \mathrm{C}$ values $(p<0.001$; Figure $6 \mathrm{~B}$ ), strengthening the hypothesis of the involvement of the coastal environment and sediments in individual $\mathrm{Hg}$ exposure. This link between $\mathrm{Hg}$ concentration and inshore/demersal affinity inferred by $\delta^{13} \mathrm{C}$ has also been found in fish from other marine environments (Bank et al., 2007; Goutte et al., 2015).

\section{Intraspecific variability determines $\mathrm{Hg}$ accumulation}

To investigate intraspecific variability in terms of foraging habitat, individual fish were grouped according to their carbon source, i.e. group 1: lowest $\delta^{13} \mathrm{C}$, suggesting offshore/pelagic habits; and group 2: highest $\delta^{13} \mathrm{C}$, indicating inshore/demersal affinity (Figure 6C). Individuals from the three species from Saloum discussed above were excluded from the analysis since their terrestrial $\delta^{13} \mathrm{C}$ signature would not assign them to a group reflecting their coastal/benthic described ecology. The k-means clustering in two groups explained $71.6 \%$ of the observed variability in $\delta^{13} \mathrm{C}$ values, demonstrating the relevance of this partitioning. Half of the species included in the clustering were split between the two groups (i.e. Group: "1 \& 2" able 1), highlighting the great discrepancy in habitat occupation of individuals from a same species. Despite this high intraspecific variability, $\mathrm{Hg}$ bioaccumulation followed the same pattern as found at the species level, with offshore/pelagic fish being less contaminated than inshore/demersal ones (KW, $\mathrm{p}<0.001$ ) (Figure 6 and Figure S2).

The trophic niche (i.e. combination of trophic level and feeding habitat) can be inferred through the use of both $\delta^{15} \mathrm{~N}$ and $\delta^{13} \mathrm{C}$ (Sardenne et al., 2016) and has been shown to determine metal exposure for marine fish (Das et al., 2000; Le Croizier et al., 2016). The trophic niche influence on mercury contamination was here investigated on a single species with a sufficient number of individuals $(n=10)$ : the Atlantic bumper Chloroscombrus chrysurus. 
Conspecifics fish showed two distinct trophic niches based on a k-means clustering, characterized by different $\delta^{15} \mathrm{~N}($ ANOVA, $p<0.05)$ and $\delta^{13} \mathrm{C}($ ANOVA, $p<0.01)$ (Figure 7). Thus, despite the low selectivity of prey in the feeding behavior of $C$. chrysurus that feeds mainly on pelagic particles (Faye et al., 2011), this result revealed again the large diversity in the trophic sources exploited by coastal consumers (Bird et al., 2018). Individuals belonging to different isotopic niches were also characterized by contrasted Hg concentrations (ANOVA, p < 0.001), the fish feeding on a more coastal food chain and at a higher trophic level being the more contaminated. This clear influence of the trophic niche in $\mathrm{Hg}$ exposure may be the result of mercury biomagnification even for forage fish such as $C$. chrysurus as well as the higher methylmercury production in estuarine waters compared to shelf waters (Figure 4).

\section{Prediction of $\mathrm{Hg}$ concentrations and impact on consumer health}

In contrast to other toxic metal elements like cadmium, that are poorly assimilated from food (Le Croizier et al., 2018), bioaccessibility of MeHg to humans from fish consumption can be high depending on the species consumed (Bradley et al., 2017) and can impair human health, mainly through neurological damage (Bosch et al., 2016). Fish consumption is also known to provide health benefits through the intake of essential nutrients such as omega- 3 fatty acids that contribute to the prevention of cerebrovascular diseases (Chowdhury et al., 2012; Rheinberger and Hammitt, 2012). However, as fish consumption constitutes the main pathway for $\mathrm{Hg}$ exposure (Driscoll et al., 2013) and fish exhibit high inter and intraspecific variability in $\mathrm{Hg}$ concentrations, attention should be focused on determining which fish are safe or should be avoided for human consumption. In this study, the low overlap of species between sites makes it difficult to draw conclusion regarding the spatial pattern of $\mathrm{Hg}$ contamination along the coast of Senegal. In this context, univariate models were used to 
predict $\mathrm{Hg}$ concentrations in individual fish taking into account species and site variability. The model with length as a predictor of $\mathrm{Hg}$ concentration was the most supported $(\triangle \mathrm{AICC}=0.00$, $w_{i}=1.00 ;$ Table S2, Supplementary Material) and explained $25 \%$ of $\mathrm{Hg}$ variation in the fish flesh. Similarly, weight explained $15 \%$ of the observed $\mathrm{Hg}$ variability. These results are in accordance with the well-described bioaccumulation of $\mathrm{Hg}$ over time due to its very slow excretion from muscle tissue (Peng et al., 2016). Moreover, taking into account the spatial variability, the habitat of the species accounted for a significant part of $\mathrm{Hg}$ variation (i.e. $26 \%$ and $16 \%$, for horizontal and vertical habitat respectively). In view of the above conclusions, this highlights the crucial role of the habitat in trophic $\mathrm{Hg}$ exposure to marine fish. Finally, models with length as a predictor of $\mathrm{Hg}$ were used without species and/or sampling site as random effects. The model with species and sampling site as random effects was again the most supported $\left(\triangle A I C c=0.00, w_{i}=1.00, R^{2} m=25 \%\right.$; Table S2 Supplementary material $)$. However, the model with only species as a random effect lead to a higher explained variability (i.e. $30 \%$ ) that demonstrates the importance of considering the species rather than the site (explaining only $4 \%$ of $\mathrm{Hg}$ variation) in predicting mercury concentrations. To sum up, these results indicate an increasing risk of mercury exposure to humans trough the consumption of larger fish (within a same species) with demersal and/or coastal habits.

In the present study, all individuals presented a muscular $\mathrm{Hg}$ concentration below the current maximum acceptable limit for seafood consumption (see Supporting Information) set by both the European Union and the Food and Agriculture Organization of the United Nations, that is $0.5 \mu \mathrm{g} \cdot \mathrm{g}-1 \mathrm{ww}$ for the species investigated here (EU, 2006; FAO, 2003). However, considering the Tolerable Weekly Intake (TWI) set by the European Food Safety Authority (EFSA), that is $1.3 \mu \mathrm{kg}^{-1}$ (bw) for MeHg (EFSA, 2012), and assuming that nearly all the bioaccumulated $\mathrm{Hg}$ is in its organic form, consumption of some species from southern locations such as Saloum 
and Casamance should be limited. Indeed, the quantity of muscle tissue consumed per day by a 70-kg person should not exceed $130 \mathrm{~g}$ for Dicologoglossa hexophthalma (Table S3, Supporting material), $118 \mathrm{~g}$ for Pseudupeneus prayensis, $108 \mathrm{~g}$ for Plectorhinchus mediterraneus and $93 \mathrm{~g}$ for Caranx rhonchus, that is among the most exploited species in the Canary Current Large Marine Ecosystem (Sambe et al., 2016). As marine products represent the main source of protein intake for the population of Senegal, especially in southern areas (FAO, 2006), overconsumption of some coastal demersal species could be of concern regarding human exposure to $\mathrm{Hg}$.

\section{Limitations of the study}

The present study shows a number of limitations that have to be considered in interpreting the results.

First, a piece of dorsal muscle was used to analyze both stable isotopes and $\mathrm{Hg}$ concentration. Thus, the obtained results might not reflect the whole fish fillet characteristics, particularly for fish species with high fat content. Indeed, lipid content can vary between the dorsal and lateral region of muscle tissues, influencing both $\delta^{13} \mathrm{C}$ values and $\mathrm{Hg}$ concentrations (Balshaw et al., 2008; Cherel et al., 2011). In this context, a mathematical correction was applied to $\delta^{13} \mathrm{C}$ values to accurately account for the effect of lipids (Post et al., 2007; Skinner et al., 2016). Moreover, no variation in $\mathrm{Hg}$ accumulation was detected within the white muscle, that constitutes the largest part of muscle tissue in marine fish (Bosch et al., 2016; O'Bryhim et al., 2017). Thus, the protocol used in this study (i.e. using a dorsal muscle portion) has been extensively applied in recent risk assessment studies (Araújo and Cedeño-Macias, 2016; Bodin et al., 2017; Nicklisch et al., 2017). Second, the risk assessment of mercury intake due to fish consumption is based on 5 individuals for each species (Table 1) and may not be representative of the $\mathrm{Hg}$ 
concentrations throughout the region. However, to date only few studies have examined $\mathrm{Hg}$ concentrations in selected marine fish species from Senegal (Diop et al., 2017; Diop and Amara, 2016), while the present study offers a broader assessment of species that may be at risk for human consumption and allows suggesting that future studies should focus on coastal and demersal fish species.

Finally, interpretation of carbon isotope data to determine feeding habitat for marine fish in coastal environments can be difficult, since carbon sources originating from opposite habitats can show similar isotopic signature (e.g. low $\delta^{13} \mathrm{C}$ values for both oceanic and terrestrial materials), especially in ecosystems under estuarine influence (Cresson et al., 2014; Darnaude, 2005; Senn et al., 2010). In the present study, despite low $\delta^{13} \mathrm{C}$ values observed in three particular coastal species from the Saloum site (red points, Fig. 6A), that is known to receive ${ }^{13} \mathrm{C}$-depleted terrestrial inputs (Faye et al., 2011; Gning et al., 2010), $\delta^{13} \mathrm{C}$ of "inshore" species was significantly higher than $\delta^{13} \mathrm{C}$ of "offshore" species, all sites combined (see Supplementary material, Figure S3; ANOVA, $p<0.001$ ). This result confirms that apart from the particular case of few fish from Saloum, low $\delta^{13} \mathrm{C}$ values are actually characteristic of the influence of offshore marine habitat rather than estuarine habitat throughout the coastal zone. However, this highlights the need to verify the significance of $\delta^{13} \mathrm{C}$ values by comparing with existing ecological data of the studied species (e.g. from stomach contents or fishery data), especially when there are multiple carbon sources such as in complex coastal ecosystems. Here, the same contamination pattern was observed with two different methods (i.e. species-specific ecological data and individual $\delta^{13} \mathrm{C}$ signatures), strengthening the hypothesis that $\mathrm{Hg}$ exposure mainly occurs trough the sediments of the benthic/coastal habitat, like previously observed in many other coastal ecosystems (Balogh et al., 2015; Gehrke et al., 2011; Sackett et al., 2015) 


\section{CONCLUSION}

Results from this study confirmed the influence of diet and habitat use in metal transfer to fish in marine environments (Le Croizier et al., 2016; Signa et al., 2017). They further highlight the great diversity in the trophic sources exploited by coastal consumers and the resulting need to consider individual foraging behavior in ecotoxicological studies. Moreover, this study revealed that the mercury previously observed in marine organisms from Senegal (Bodin et al., 2013; Diop and Amara, 2016; Net et al., 2015) is likely to originate from estuarine and sedimentary sources. Recently, $\mathrm{Hg}$ isotopic signatures have been used to characterize the complex biogeochemical cycle of this contaminant. $\mathrm{Hg}$ isotopes allowed to identify primary food sources of the accumulated-Hg in marine fish (Sackett et al., 2017, 2015) and to determine the habitats leading to $\mathrm{Hg}$ exposure, by discriminating between estuarine and oceanic affinities (Li et al., 2016, Senn et al., 2010) or benthic versus pelagic habits (Gehrke et al., 2011). These innovative analytical techniques, as well as the carbon stable isotope analysis of methylmercury (Masbou et al., 2015), are thus promising tools to get better insights in the origin, fate and ecodynamics of mercury in the marine food webs of this region with high fishing potential.

\section{ACKNOWLEDGEMENTS}

The authors greatly thank Jean Raffray for the identification and dissection of the fish. Samples used in this study were collected during a scientific cruise (doi, 10.17600/14001400) of the BMBF - IRD AWA Project Ecosystem Approach to the management of fisheries and the marine environment in West African waters (01DG12073E). We thank Mohamed Taleb (IMROP) and 
Mor Sylla (CRODT) for onboard sample sorting. This work was financially supported by the

French National Research Agency project ANR-11-CEPL-0005 EPURE.

\section{REFERENCES}

Akadje, C., Diaby, M., Le Loc'h, F., Konan, J.K., N'da, K., 2013. Diet of the barracuda Sphyraena guachancho in Cote d'Ivoire (Equatorial Eastern Atlantic Ocean). Cybium 37, 285-293.

Andersen, J.L., Depledge, M.H., 1997. A survey of total mercury and methylmercury in edible fish and invertebrates from Azorean waters. Marine Environmental Research 44, 331350. https://doi.org/10.1016/S0141-1136(97)00011-1

Araújo, C.V.M., Cedeño-Macias, L.A., 2016. Heavy metals in yellowfin tuna (Thunnus albacares) and common dolphinfish (Coryphaena hippurus) landed on the Ecuadorian coast. Science of The Total Environment 541, 149-154. https://doi.org/10.1016/j.scitotenv.2015.09.090

Auger, P.A., Machu, E., Gorgues, T., Grima, N., Waeles, M., 2015. Comparative study of potential transfer of natural and anthropogenic cadmium to plankton communities in the North-West African upwelling. Science of The Total Environment 505, 870-888. https://doi.org/10.1016/j.scitotenv.2014.10.045

Balcom, P.H., Schartup, A.T., Mason, R.P., Chen, C.Y., 2015. Sources of water column methylmercury across multiple estuaries in the Northeast U.S. Marine Chemistry 177, Part 5, 721-730. https://doi.org/10.1016/j.marchem.2015.10.012

Balogh, S.J., Tsui, M.T.-K., Blum, J.D., Matsuyama, A., Woerndle, G.E., Yano, S., Tada, A., 2015. Tracking the Fate of Mercury in the Fish and Bottom Sediments of Minamata Bay, Japan, Using Stable Mercury Isotopes. Environ. Sci. Technol. 49, 5399-5406. https://doi.org/10.1021/acs.est.5b00631

Balshaw, S., Edwards, J.W., Ross, K.E., Daughtry, B.J., 2008. Mercury distribution in the muscular tissue of farmed southern bluefin tuna (Thunnus maccoyii) is inversely related to the lipid content of tissues. Food Chemistry 111, 616-621. https://doi.org/10.1016/j.foodchem.2008.04.041

Bank, M.S., Chesney, E., Shine, J.P., Maage, A., Senn, D.B., 2007. Mercury Bioaccumulation and Trophic Transfer in Sympatric Snapper Species from the Gulf of Mexico. Ecological Applications 17, 2100-2110. https://doi.org/10.1890/06-1422.1

Bartlett, M.S., 1937. Properties of sufficiency and statistical tests. Proc. R. Soc. Lond. A 160, 268-282. https://doi.org/10.1098/rspa.1937.0109

Bates, D., Mächler, M., Bolker, B., Walker, S., 2014. Fitting Linear Mixed-Effects Models using lme4. arXiv:1406.5823 [stat].

Bird, C.S., Veríssimo, A., Magozzi, S., Abrantes, K.G., Aguilar, A., Al-Reasi, H., Barnett, A., Bethea, D.M., Biais, G., Borrell, A., Bouchoucha, M., Boyle, M., Brooks, E.J., Brunnschweiler, J., Bustamante, P., Carlisle, A., Catarino, D., Caut, S., Cherel, Y., Chouvelon, T., Churchill, D., Ciancio, J., Claes, J., Colaço, A., Courtney, D.L., Cresson, P., Daly, R., Necker, L. de, Endo, T., Figueiredo, I., Frisch, A.J., Hansen, J.H., Heithaus, M., Hussey, N.E., Iitembu, J., Juanes, F., Kinney, M.J., Kiszka, J.J., Klarian, S.A., Kopp, D., Leaf, R., Li, Y., Lorrain, A., Madigan, D.J., Maljković, A., Malpica-Cruz, L., 
Matich, P., Meekan, M.G., Ménard, F., Menezes, G.M., Munroe, S.E.M., Newman, M.C., Papastamatiou, Y.P., Pethybridge, H., Plumlee, J.D., Polo-Silva, C., QuaeckDavies, K., Raoult, V., Reum, J., Torres-Rojas, Y.E., Shiffman, D.S., Shipley, O.N., Speed, C.W., Staudinger, M.D., Teffer, A.K., Tilley, A., Valls, M., Vaudo, J.J., Wai, T.-C., Wells, R.J.D., Wyatt, A.S.J., Yool, A., Trueman, C.N., 2018. A global perspective on the trophic geography of sharks. Nature Ecology \& Evolution 2, 299 305. https://doi.org/10.1038/s41559-017-0432-z

Bloom, N.S., 1992. On the Chemical Form of Mercury in Edible Fish and Marine Invertebrate Tissue. Can. J. Fish. Aquat. Sci. 49, 1010-1017. https://doi.org/10.1139/f92-113

Blum, J.D., Popp, B.N., Drazen, J.C., Anela Choy, C., Johnson, M.W., 2013. Methylmercury production below the mixed layer in the North Pacific Ocean. Nature Geosci 6, 879884. https://doi.org/10.1038/ngeo1918

Bodin, N., Lesperance, D., Albert, R., Hollanda, S., Michaud, P., Degroote, M., Churlaud, C., Bustamante, P., 2017. Trace elements in oceanic pelagic communities in the western Indian Ocean. Chemosphere 174, 354-362. https://doi.org/10.1016/j.chemosphere.2017.01.099

Bodin, N., N'Gom-Kâ, R., Kâ, S., Thiaw, O.T., Tito de Morais, L., Le Loc'h, F., RozuelChartier, E., Auger, D., Chiffoleau, J.-F., 2013. Assessment of trace metal contamination in mangrove ecosystems from Senegal, West Africa. Chemosphere 90, 150-157. https://doi.org/10.1016/j.chemosphere.2012.06.019

Boëly, T., Wysokinski, A., Elwertowski, J., 1973. Les chinchards des côtes sénégalaises et mauritaniennes : biologie - déplacements - ressources, Document Scientifique Provisoire. ORSTOM, Dakar.

Bosch, A.C., O’Neill, B., Sigge, G.O., Kerwath, S.E., Hoffman, L.C., 2016. Mercury accumulation in Yellowfin tuna (Thunnus albacares) with regards to muscle type, muscle position and fish size. Food Chemistry 190, 351-356. https://doi.org/10.1016/j.foodchem.2015.05.109

Bosch, O’Neill, B., Sigge, G.O., Kerwath, S.E., Hoffman, L.C., 2016. Heavy metals in marine fish meat and consumer health: a review. J. Sci. Food Agric. 96, 32-48. https://doi.org/10.1002/jsfa.7360

Bradley, M., Barst, B., Basu, N., Bradley, M.A., Barst, B.D., Basu, N., 2017. A Review of Mercury Bioavailability in Humans and Fish. International Journal of Environmental Research and Public Health 14, 169. https://doi.org/10.3390/ijerph14020169

Burnham, K.P., Anderson, D.R., 2002. Model Selection and Multimodel Inference: A Practical Information-Theoretic Approach, 2nd ed. Springer-Verlag, New York.

Caliński, T., Harabasz, J., 1974. A dendrite method for cluster analysis. Communications in Statistics 3, 1-27. https://doi.org/10.1080/03610927408827101

Castro, J.J., 1993. Feeding ecology of chub mackerel Scomber japonicus in the Canary islands area. South African Journal of Marine Science 13, 323-328. https://doi.org/10.2989/025776193784287400

Caverivière, A., 1993. Les peuplements ichtyologiques démersaux : écologie et biologie, in: Le Loeuff, P., Marchal, E., Amon Kothias, J.B. (Eds.), Environnement et ressources aquatiques de Côte d'Ivoire : 1. Le milieu marin. ORSTOM, Paris, pp. 271-320.

Chen, C.Y., Folt, C.L., 2005. High Plankton Densities Reduce Mercury Biomagnification. Environ. Sci. Technol. 39, 115-121. https://doi.org/10.1021/es0403007

Cherel, Y., Koubbi, P., Giraldo, C., Penot, F., Tavernier, E., Moteki, M., Ozouf-Costaz, C., Causse, R., Chartier, A., Hosie, G., 2011. Isotopic niches of fishes in coastal, neritic and oceanic waters off Adélie land, Antarctica. Polar Science, CEAMARC - The Collaborative East Antarctic Marine Census for the Census of Antarctic Marine Life 5, 286-297. https://doi.org/10.1016/j.polar.2010.12.004 
Choe, K.-Y., Gill, G.A., 2003. Distribution of particulate, colloidal, and dissolved mercury in San Francisco Bay estuary. 2. Monomethyl mercury. Limnol. Oceanogr. 48, 15471556. https://doi.org/10.4319/lo.2003.48.4.1547

Chouvelon, T., Caurant, F., Cherel, Y., Simon-Bouhet, B., Spitz, J., Bustamante, P., 2014. Species- and size-related patterns in stable isotopes and mercury concentrations in fish help refine marine ecosystem indicators and provide evidence for distinct management units for hake in the Northeast Atlantic. ICES J Mar Sci 71, 1073-1087. https://doi.org/10.1093/icesjms/fst199

Chouvelon, T., Cresson, P., Bouchoucha, M., Brach-Papa, C., Bustamante, P., Crochet, S., Marco-Miralles, F., Thomas, B., Knoery, J., 2018. Oligotrophy as a major driver of mercury bioaccumulation in medium-to high-trophic level consumers: A marine ecosystem-comparative study. Environmental Pollution 233, 844-854. https://doi.org/10.1016/j.envpol.2017.11.015

Chouvelon, T., Spitz, J., Caurant, F., Mèndez-Fernandez, P., Autier, J., Lassus-Débat, A., Chappuis, A., Bustamante, P., 2012. Enhanced bioaccumulation of mercury in deep-sea fauna from the Bay of Biscay (north-east Atlantic) in relation to trophic positions identified by analysis of carbon and nitrogen stable isotopes. Deep Sea Research Part I: Oceanographic Research Papers 65, 113-124. https://doi.org/10.1016/j.dsr.2012.02.010

Chowdhury, R., Stevens, S., Gorman, D., Pan, A., Warnakula, S., Chowdhury, S., Ward, H., Johnson, L., Crowe, F., Hu, F.B., Franco, O.H., 2012. Association between fish consumption, long chain omega 3 fatty acids, and risk of cerebrovascular disease: systematic review and meta-analysis. BMJ 345, e6698. https://doi.org/10.1136/bmj.e6698

Choy, C.A., Popp, B.N., Kaneko, J.J., Drazen, J.C., 2009. The influence of depth on mercury levels in pelagic fishes and their prey. PNAS 106, 13865-13869. https://doi.org/10.1073/pnas.0900711106

Condini, M.V., Hoeinghaus, D.J., Roberts, A.P., Soulen, B.K., Garcia, A.M., 2017. Mercury concentrations in dusky grouper Epinephelus marginatus in littoral and neritic habitats along the Southern Brazilian coast. Marine Pollution Bulletin 115, 266-272. https://doi.org/10.1016/j.marpolbul.2016.12.006

Conover, W.J., Iman, R.L., 1979. Multiple-comparisons procedures. Informal report (No. LA7677-MS). Los Alamos Scientific Lab., NM (USA).

Correia, R.R.S., Guimarães, J.R.D., 2017. Mercury methylation and sulfate reduction rates in mangrove sediments, Rio de Janeiro, Brazil: The role of different microorganism consortia. Chemosphere 167, 438-443. https://doi.org/10.1016/j.chemosphere.2016.09.153

Cossa, D., Coquery, M., 2005. The Mediterranean Mercury Anomaly, a Geochemical or a BiologocalIssue 177-208. https://doi.org/10.1007/b107147

Cossa, D., Coquery, M., Gobeil, C., Martin, J.-M., 1996. Mercury Fluxes at the Ocean Margins, in: Baeyens, W., Ebinghaus, R., Vasiliev, O. (Eds.), Global and Regional Mercury Cycles: Sources, Fluxes and Mass Balances, NATO ASI Series. Springer Netherlands, pp. 229-247. https://doi.org/10.1007/978-94-009-1780-4_11

Cossa, D., Durrieu de Madron, X., Schäfer, J., Lanceleur, L., Guédron, S., Buscail, R., Thomas, B., Castelle, S., Naudin, J.-J., 2017. The open sea as the main source of methylmercury in the water column of the Gulf of Lions (Northwestern Mediterranean margin). Geochimica et Cosmochimica Acta 199, 222-237. https://doi.org/10.1016/j.gca.2016.11.037

Cossa, D., Harmelin-Vivien, M., Mellon-Duval, C., Loizeau, V., Averty, B., Crochet, S., Chou, L., Cadiou, J.-F., 2012. Influences of Bioavailability, Trophic Position, and Growth on Methylmercury in Hakes (Merluccius merluccius) from Northwestern Mediterranean 
and Northeastern Atlantic. Environ. Sci. Technol. 46, 4885-4893. https://doi.org/10.1021/es204269w

Cresson, P., Fabri, M.C., Bouchoucha, M., Brach Papa, C., Chavanon, F., Jadaud, A., Knoery, J., Miralles, F., Cossa, D., 2014. Mercury in organisms from the Northwestern Mediterranean slope: Importance of food sources. Science of The Total Environment 497-498, 229-238. https://doi.org/10.1016/j.scitotenv.2014.07.069

Darnaude, A.M., 2005. Fish ecology and terrestrial carbon use in coastal areas: implications for marine fish production. Journal of Animal Ecology 74, 864-876. https://doi.org/10.1111/j.1365-2656.2005.00978.x

Das, K., Lepoint, G., Loizeau, V., Debacker, V., Dauby, P., Bouquegneau, J.M., 2000. Tuna and Dolphin Associations in the North-east Atlantic: Evidence of Different Ecological Niches from Stable Isotope and Heavy Metal Measurements. Marine Pollution Bulletin 40, 102-109. https://doi.org/10.1016/S0025-326X(99)00178-2

Derbal, P., Hichem Kara, M., 2008. Composition du régime alimentaire du bogue Boops boops (Sparidae) dans le golfe d'Annaba (Algérie). Cybium 32, 325-333.

Diop, M., Amara, R., 2016. Mercury concentrations in the coastal marine food web along the Senegalese coast. Environ Sci Pollut Res 23, 11975-11984. https://doi.org/10.1007/s11356-016-6386-X

Diop, M., Net, S., Howsam, M., Lencel, P., Watier, D., Grard, T., Duflos, G., Diouf, A., Amara, R., 2017. Concentrations and Potential Human Health Risks of Trace Metals $(\mathrm{Cd}, \mathrm{Pb}$, $\mathrm{Hg}$ ) and Selected Organic Pollutants (PAHs, PCBs) in Fish and Seafood from the Senegalese Coast. Int J Environ Res 11, 349-358. https://doi.org/10.1007/s41742-0170032-4

Diouf, P.S., 1996. Les peuplements de poissons des milieux estuariens de l'Afrique de l'Ouest : l'exemple de l'estuaire hyperhalin du Sine-Saloum. ORSTOM, Paris.

Driscoll, C.T., Mason, R.P., Chan, H.M., Jacob, D.J., Pirrone, N., 2013. Mercury as a Global Pollutant: Sources, Pathways, and Effects. Environ. Sci. Technol. 47, 4967-4983. https://doi.org/10.1021/es305071v

EFSA, 2012. Scientific Opinion on the risk for public health related to the presence of mercury and methylmercury in food. EFSA Journal 10, 2985. https://doi.org/10.2903/j.efsa.2012.2985

FAO. Report of the FAO Working Group on the Assessment of Small Pelagic Fish off Northwest Africa.FAO Fisheries Report, Banjul, Gambia, pp. 2e11, 811, 192 pp., 2006.

Faye, D., Tito de Morais, L., Raffray, J., Sadio, O., Thiaw, O.T., Le Loc'h, F., 2011. Structure and seasonal variability of fish food webs in an estuarine tropical marine protected area (Senegal): Evidence from stable isotope analysis. Estuarine, Coastal and Shelf Science 92, 607-617. https://doi.org/10.1016/j.ecss.2011.02.017

Fitzgerald, W.F., Lamborg, C.H., Hammerschmidt, C.R., 2007. Marine biogeochemical cycling of mercury. Chem. Rev. 107, 641-662. https://doi.org/10.1021/cr050353m

Froese, R., Pauly, D., 2018. FishBase [WWW Document]. World Wide Web electronic publication Web electronic publication.www.fishbase.org. URL http://www.fishbase.org/search.php (accessed 4.11.17).

Gehrke, G.E., Blum, J.D., Slotton, D.G., Greenfield, B.K., 2011. Mercury Isotopes Link Mercury in San Francisco Bay Forage Fish to Surface Sediments. Environ. Sci. Technol. 45, 1264-1270. https://doi.org/10.1021/es103053y

Gilmour, C.C., Podar, M., Bullock, A.L., Graham, A.M., Brown, S.D., Somenahally, A.C., Johs, A., Hurt, R.A., Bailey, K.L., Elias, D.A., 2013. Mercury Methylation by Novel Microorganisms from New Environments. Environ. Sci. Technol. 47, 11810-11820. https://doi.org/10.1021/es403075t 
Gning, N., Le Loc'h, F., Thiaw, O.T., Aliaume, C., Vidy, G., 2010. Estuarine resources use by juvenile Flagfin mojarra (Eucinostomus melanopterus) in an inverse tropical estuary (Sine Saloum, Senegal). Estuarine, Coastal and Shelf Science 86, 683-691. https://doi.org/10.1016/j.ecss.2009.11.037

Goutte, A., Cherel, Y., Churlaud, C., Ponthus, J.-P., Massé, G., Bustamante, P., 2015. Trace elements in Antarctic fish species and the influence of foraging habitats and dietary habits on mercury levels. Science of The Total Environment 538, 743-749. https://doi.org/10.1016/j.scitotenv.2015.08.103

Hammerschmidt, C.R., Fitzgerald, W.F., 2006. Methylmercury cycling in sediments on the continental shelf of southern New England. Geochimica et Cosmochimica Acta 70, 918-930. https://doi.org/10.1016/j.gca.2005.10.020

Hartigan, J.A., Wong, M.A., 1979. Algorithm AS 136: A K-Means Clustering Algorithm. Journal of the Royal Statistical Society. Series C (Applied Statistics) 28, 100-108. https://doi.org/10.2307/2346830

Heimbürger, L.-E., Cossa, D., Marty, J.-C., Migon, C., Averty, B., Dufour, A., Ras, J., 2010. Methyl mercury distributions in relation to the presence of nano- and picophytoplankton in an oceanic water column (Ligurian Sea, North-western Mediterranean). Geochimica et Cosmochimica Acta 74, 5549-5559. https://doi.org/10.1016/j.gca.2010.06.036

Horta, M., Costa, M.J., Cabral, H., 2004. Spatial and trophic niche overlap between Diplodus bellottii and Diplodus vulgaris in the Tagus estuary, Portugal. Journal of the Marine Biological Association of the United Kingdom 84, 837-842. https://doi.org/10.1017/S0025315404010033h

Interwies, E., Görlitz, S., 2013. Economic and Social Valuation of the CCLME Ecosystem Services. Rapport au Groupe de travail socioéconomie et commerce du CCLME. 50.

Jaeger, B., 2017. r2glmm: Computes R Squared for Mixed (Multilevel) Models. R package version 0.1.2.

Kidd, K., Batchelar, K., 2011. 5 - Mercury, in: Wood, C.M., Farrell, A.P., Brauner, C.J. (Eds.), Fish Physiology, Homeostasis and Toxicology of Non-Essential Metals. Academic Press, pp. 237-295. https://doi.org/10.1016/S1546-5098(11)31027-8

Kiszka, J.J., Aubail, A., Hussey, N.E., Heithaus, M.R., Caurant, F., Bustamante, P., 2015. Plasticity of trophic interactions among sharks from the oceanic south-western Indian Ocean revealed by stable isotope and mercury analyses. Deep Sea Research Part I: Oceanographic Research Papers 96, 49-58. https://doi.org/10.1016/j.dsr.2014.11.006

Lambertsson, L., Nilsson, M., 2006. Organic Material: The Primary Control on Mercury Methylation and Ambient Methyl Mercury Concentrations in Estuarine Sediments. Environ. Sci. Technol. 40, 1822-1829. https://doi.org/10.1021/es051785h

Le Croizier, G., Lacroix, C., Artigaud, S., Le Floch, S., Raffray, J., Penicaud, V., Coquillé, V., Autier, J., Rouget, M.-L., Le Bayon, N., Laë, R., Tito De Morais, L., 2018. Significance of metallothioneins in differential cadmium accumulation kinetics between two marine fish species. Environmental Pollution 236, 462-476. https://doi.org/10.1016/j.envpol.2018.01.002

Le Croizier, G., Schaal, G., Gallon, R., Fall, M., Le Grand, F., Munaron, J.-M., Rouget, M.-L., Machu, E., Le Loc'h, F., Laë, R., De Morais, L.T., 2016. Trophic ecology influence on metal bioaccumulation in marine fish: Inference from stable isotope and fatty acid analyses. Science of The Total Environment 573, 83-95. https://doi.org/10.1016/j.scitotenv.2016.08.035

Lehnherr, I., Louis, V.L.S., Hintelmann, H., Kirk, J.L., 2011. Methylation of inorganic mercury in polar marine waters. Nature Geosci 4, 298-302. https://doi.org/10.1038/ngeo1134

Magalhães, M.C., Costa, V., Menezes, G.M., Pinho, M.R., Santos, R.S., Monteiro, L.R., 2007. Intra- and inter-specific variability in total and methylmercury bioaccumulation by eight 
marine fish species from the Azores. Marine Pollution Bulletin 54, 1654-1662. https://doi.org/10.1016/j.marpolbul.2007.07.006

Masbou, J., Point, D., Guillou, G., Sonke, J.E., Lebreton, B., Richard, P., 2015. Carbon Stable Isotope Analysis of Methylmercury Toxin in Biological Materials by Gas Chromatography Isotope Ratio Mass Spectrometry. Anal. Chem. 87, 11732-11738. https://doi.org/10.1021/acs.analchem.5b02918

McKinney, M.A., Dean, K., Hussey, N.E., Cliff, G., Wintner, S.P., Dudley, S.F.J., Zungu, M.P., Fisk, A.T., 2016. Global versus local causes and health implications of high mercury concentrations in sharks from the east coast of South Africa. Science of The Total Environment 541, 176-183. https://doi.org/10.1016/j.scitotenv.2015.09.074

McMeans, B.C., Svavarsson, J., Dennard, S., Fisk, A.T., 2010. Diet and resource use among Greenland sharks (Somniosus microcephalus) and teleosts sampled in Icelandic waters, using $\delta 13 \mathrm{C}, \delta 15 \mathrm{~N}$, and mercury. Can. J. Fish. Aquat. Sci. 67, 1428-1438. https://doi.org/10.1139/F10-072

Meredith, M., 2017. wiqid: Quick and Dirty Estimates for Wildlife Populations. R package version 0.1.3.

Merritt, K.A., Amirbahman, A., 2009. Mercury methylation dynamics in estuarine and coastal marine environments — A critical review. Earth-Science Reviews 96, 54-66. https://doi.org/10.1016/j.earscirev.2009.06.002

Messié, M., Chavez, F.P., 2015. Seasonal regulation of primary production in eastern boundary upwelling systems. Progress in Oceanography 134, 1-18. https://doi.org/10.1016/j.pocean.2014.10.011

Nakagawa Shinichi, Schielzeth Holger, O'Hara Robert B., 2012. A general and simple method for obtaining R2 from generalized linear mixed- effects models. Methods in Ecology and Evolution 4, 133-142. https://doi.org/10.1111/j.2041-210x.2012.00261.x

Ndoye, S., 2016. Fonctionnement dynamique du centre d'upwelling sud-sénégalais : approche par la modélisation réaliste et l'analyse d'observations satellite de température de surface de la mer.

Ndoye, S., Capet, X., Estrade, P., Sow, B., Machu, E., Brochier, T., Döring, J., Brehmer, P., 2017. Dynamics of a "low-enrichment high-retention" upwelling center over the southern Senegal shelf. Geophys. Res. Lett. 2017 GL072789. https://doi.org/10.1002/2017GL072789

Net, S., Henry, F., Rabodonirina, S., Diop, M., Merhaby, D., Mahfouz, C., Amara, R., Ouddane, B., 2015. Accumulation of PAHs, Me-PAHs, PCBs and total Mercury in sediments and Marine Species in Coastal Areas of Dakar, Senegal: Contamination level and impact. Int. J. Environ. Res 9, 419-432.

Niane, B., Guédron, S., Moritz, R., Cosio, C., Ngom, P.M., Deverajan, N., Pfeifer, H.R., Poté, J., 2015. Human exposure to mercury in artisanal small-scale gold mining areas of Kedougou region, Senegal, as a function of occupational activity and fish consumption. Environ Sci Pollut Res 22, 7101-7111. https://doi.org/10.1007/s11356-014-3913-5

Nicklisch, S.C.T., Bonito, L.T., Sandin, S., Hamdoun, A., 2017. Mercury levels of yellowfin tuna (Thunnus albacares) are associated with capture location. Environmental Pollution 229, 87-93. https://doi.org/10.1016/j.envpol.2017.05.070

O’Bryhim, J.R., Adams, D.H., Spaet, J.L.Y., Mills, G., Lance, S.L., 2017. Relationships of mercury concentrations across tissue types, muscle regions and fins for two shark species. Environmental Pollution 323-333. https://doi.org/10.1016/j.envpol.2017.01.029

Official Journal of the European Union, 2006. Commission Regulation (EC) No 1881/2006 of 19 December 2006 setting maximum levels for certain contaminants in foodstuffs. 
Paranjape, A.R., Hall, B.D., 2017. Recent advances in the study of mercury methylation in aquatic systems. FACETS. https://doi.org/10.1139/facets-2016-0027

Peng, X., Liu, F., Wang, W.-X., 2016. Organ-specific accumulation, transportation, and elimination of methylmercury and inorganic mercury in a low $\mathrm{Hg}$ accumulating fish. Environ Toxicol Chem 35, 2074-2083. https://doi.org/10.1002/etc.3363

Pethybridge, H., Butler, E.C.V., Cossa, D., Daley, R., Boudou, A., 2012. Trophic structure and biomagnification of mercury in an assemblage of deepwater chondrichthyans from southeastern Australia. Mar Ecol Prog Ser 451, 163-174. https://doi.org/10.3354/meps09593

Pethybridge, H., Cossa, D., Butler, E.C.V., 2010. Mercury in 16 demersal sharks from southeast Australia: Biotic and abiotic sources of variation and consumer health implications. $\begin{array}{llll}\text { Marine Environmental } & \text { Research } & \text { 18-26. }\end{array}$ https://doi.org/10.1016/j.marenvres.2009.07.006

Podar, M., Gilmour, C.C., Brandt, C.C., Soren, A., Brown, S.D., Crable, B.R., Palumbo, A.V., Somenahally, A.C., Elias, D.A., 2015. Global prevalence and distribution of genes and microorganisms involved in mercury methylation. Science Advances 1, e1500675. https://doi.org/10.1126/sciadv.1500675

Post, D.M., 2002. Using Stable Isotopes to Estimate Trophic Position: Models, Methods, and Assumptions. Ecology 83, 703-718. https://doi.org/10.1890/00129658(2002)083[0703:USITET]2.0.CO;2

Post, D.M., Layman, C.A., Arrington, D.A., Takimoto, G., Quattrochi, J., Montaña, C.G., 2007. Getting to the fat of the matter: models, methods and assumptions for dealing with lipids in stable isotope analyses. Oecologia 152, 179-189. https://doi.org/10.1007/s00442006-0630-X

Rheinberger, C.M., Hammitt, J.K., 2012. Risk Trade-Offs in Fish Consumption: A Public Health Perspective. Environ. Sci. Technol. 46, 12337-12346. https://doi.org/10.1021/es302652m

Sackett, D.K., Drazen, J.C., Choy, C.A., Popp, B., Pitz, G.L., 2015. Mercury Sources and Trophic Ecology for Hawaiian Bottomfish. Environ. Sci. Technol. 49, 6909-6918. https://doi.org/10.1021/acs.est.5b01009

Sackett, D.K., Drazen, J.C., Popp, B.N., Choy, C.A., Blum, J.D., Johnson, M.W., 2017. Carbon, Nitrogen, and Mercury Isotope Evidence for the Biogeochemical History of Mercury in Hawaiian Marine Bottomfish. Environ. Sci. Technol. 51, 13976-13984. https://doi.org/10.1021/acs.est.7b04893

Sambe, B., Tandstad, M., Caramelo, A.M., Brown, B.E., 2016. Variations in productivity of the Canary Current Large Marine Ecosystem and their effects on small pelagic fish stocks. Environmental Development, Thematic Issue - Ecosystem Based Management of Large Marine Ecosystems 17, Supplement 1, 105-117. https://doi.org/10.1016/j.envdev.2015.11.012

Sardenne, F., Bodin, N., Chassot, E., Amiel, A., Fouché, E., Degroote, M., Hollanda, S., Pethybridge, H., Lebreton, B., Guillou, G., Ménard, F., 2016. Trophic niches of sympatric tropical tuna in the Western Indian Ocean inferred by stable isotopes and neutral fatty acids. Progress in Oceanography 146, 75-88. https://doi.org/10.1016/j.pocean.2016.06.001

Senn, D.B., Chesney, E.J., Blum, J.D., Bank, M.S., Maage, A., Shine, J.P., 2010. Stable isotope $(\mathrm{N}, \mathrm{C}, \mathrm{Hg}$ ) study of methylmercury sources and trophic transfer in the northern gulf of Mexico. Environ. Sci. Technol. 44, 1630-1637. https://doi.org/10.1021/es902361j

Séret, B., 2011. Poissons de mer de l'Ouest africain tropical. IRD Editions.

Shapiro, S.S., Wilk, M.B., 1965. An Analysis of Variance Test for Normality (Complete Samples). Biometrika 52, 591-611. https://doi.org/10.2307/2333709 
Signa, G., Mazzola, A., Tramati, C.D., Vizzini, S., 2017. Diet and habitat use influence Hg and $\mathrm{Cd}$ transfer to fish and consequent biomagnification in a highly contaminated area: Augusta Bay (Mediterranean Sea). Environmental Pollution 230, 394-404. https://doi.org/10.1016/j.envpol.2017.06.027

Skinner, M.M., Martin, A.A., Moore, B.C., 2016. Is lipid correction necessary in the stable isotope analysis of fish tissues? Rapid Communications in Mass Spectrometry 30, 881889. https://doi.org/10.1002/rcm.7480

Sley, A., Jarboui, O., Ghorbel, M., Bouain, A., 2008. Diet composition and food habits of Caranx rhonchus (Carangidae) from the Gulf of Gabes (central Mediterranean). Journal of the Marine Biological Association of the United Kingdom 88, 831-836. https://doi.org/10.1017/S0025315408001379

Storelli, M.M., Giacominelli-Stuffler, R., Storelli, A., D’Addabbo, R., Palermo, C., Marcotrigiano, G.O., 2003. Survey of total mercury and methylmercury levels in edible fish from the Adriatic Sea. Food Additives \& Contaminants 20, 1114-1119. https://doi.org/10.1080/02652030310001622773

Streets, D.G., Devane, M.K., Lu, Z., Bond, T.C., Sunderland, E.M., Jacob, D.J., 2011. All-Time Releases of Mercury to the Atmosphere from Human Activities. Environ. Sci. Technol. 45, 10485-10491. https://doi.org/10.1021/es202765m

Szczebak, J.T., Taylor, D.L., 2011. Ontogenetic patterns in bluefish (Pomatomus saltatrix) feeding ecology and the effect on mercury biomagnification. Environmental Toxicology and Chemistry 30, 1447-1458. https://doi.org/10.1002/etc.516

UN Food and Agriculture Organization (FAO). Heavy Metals Regulations Legal Notice No 66/2003. FAO, Rome., 2003.

Wang, R., Wang, W.-X., 2018. Diet-specific trophic transfer of mercury in tilapia (Oreochromis niloticus): Biodynamic perspective. Environmental Pollution 234, 288-296. https://doi.org/10.1016/j.envpol.2017.11.071

Wang, W., Wong, R.S.K., 2003. Bioaccumulation kinetics and exposure pathways of inorganic mercury and methylmercury in a marine fish, the sweetlips Plectorhinchus gibbosus. Mar Ecol Prog Ser 261, 257-268. https://doi.org/10.3354/meps261257

Wang, X., Wang, W.-X., 2015. Physiologically Based Pharmacokinetic Model for Inorganic and Methylmercury in a Marine Fish. Environ. Sci. Technol. 49, 10173-10181. https://doi.org/10.1021/acs.est.5b02301

Zuur, A., Ieno, E.N., Walker, N., Saveliev, A.A., Smith, G.M., 2009. Mixed Effects Models and Extensions in Ecology with R, Statistics for Biology and Health. Springer-Verlag, New York. 
Figure 1: Sampling sites along the Senegalese coast (West Africa). Saint-Louis, Saloum and Casamance are located off estuaries, while Dakar is located along a rocky coast.

Figure 2: Boxplots of the mercury concentration ( $\mathrm{Hg}$ in $\mu \mathrm{g} \cdot \mathrm{g}-1 \mathrm{dry}$ weight) in muscles of fish from different sites (Saint-Louis, $n=24$; Dakar, $n=29$; Saloum, $n=44$; Casamance, $n=35$ ). The box length represents the interquartile range, the bar length represents the range, and the horizontal line is the median value. Different letters indicate a significant difference between sites (ANOVA followed by Tukey's HSD test; $p<0.01$ ).

Figure 3: Boxplots of the mercury $(\mathrm{Hg})$ concentration ( $\mu \mathrm{g} \cdot \mathrm{g}-1$ dry weight) in muscle of fish species according to their proximity to the coast ( $A$ : Offshore, $n=34$; Inshore, $n=98$ ) and according to water column distribution (B: Pelagic, $n=20$; Benthopelagic, $n=34$; Demersal, $n$ $=78$ ). The box length represents the interquartile range, the bar length represents the range, and the horizontal line is the median value. Different letters indicate a significant difference between groups (ANOVA followed by Tukey's HSD test; A: $p<0.001, B: p<0.01$ ).

Figure 4: Schematic representation of major processes supposed to be involved in $\mathrm{Hg}$ accumulation in marine fish species from the Senegalese coast. River inputs carry organic matter (OM) and particulate inorganic $\mathrm{Hg}$ to the coastal environment. After particles sink, $\mathrm{Hg}$ is methylated by bacterial activity, becoming highly bioavailable to fish foraging near the sediments (i.e. demersal species and, to a lesser extent, benthopelagic species). Methylmercury ( $\mathrm{MeHg}$ ) is rapidly accumulated by the biota, and concentrations decrease away from the coast. MeHg is also supposedly transported nearshore by a coastal current resulting from the upwelling activity. Near the surface, photochemical degradation of $\mathrm{MeHg}$ leads to formation of inorganic $\mathrm{Hg}$, which is poorly assimilated by pelagic fish.

Figure 5: Mercury ( $\mathrm{Hg}$ ) concentration ( $\mu \mathrm{g} \cdot \mathrm{g}-1 \mathrm{dry}$ weight) in muscles of individual fish vs. muscle $\delta^{15} \mathrm{~N}(\%)$ signature from the different study sites (A: Saint-Louis; B: Dakar; C: Saloum; D: Casamance). Data fit a linear curve in $A$ and an exponential curve in $B$, no correlation was found in C and D.

Figure 6: Mercury $(\mathrm{Hg})$ concentration ( $\mu \mathrm{g} \cdot \mathrm{g}-1 \mathrm{dry}$ weight) in muscles of individual fish vs. muscle $\delta^{13} \mathrm{C}(\%)$ signature from "Saloum" station (A), from the other sites, i.e. Saint-Louis, Dakar and Casamance (B), and from all sites combined except the red points from Saloum (C). Data fit a polynomial curve in $A$ and a linear curve in $B$. The former is due to the low $\delta^{13} \mathrm{C}$ of 
the red-colored individuals despite their well-known coastal ecology, suggesting the assimilation of terrestrial rather than oceanic carbon. In $\mathrm{C}$ the two groups determined trough k-means clustering on individual $\delta^{13} \mathrm{C}$ values explained $71.6 \%$ of the observed variability and significantly differed in $\delta^{13} \mathrm{C}$ values (C: Group 1, $n=63$; Group 2, $n=69$; ANOVA, $p<0.001$ ).

Figure 7: Individual stable isotope values $\left(\delta^{15} \mathrm{~N}\right.$ and $\left.\delta^{13} \mathrm{C}\right)$ in the Atlantic bumper Chloroscombrus chrysurus sampled in Casamance during this study. Colors indicate two trophic niches determined by a K-means cluster analysis. The two groups are characterized by different $\delta^{15} \mathrm{~N}$ (ANOVA, $\mathrm{p}<0.05$ ) and $\delta^{13} \mathrm{C}$ (ANOVA, $\mathrm{p}<0.01$ ) and muscle mercury concentrations (ANOVA, $p<0.001$ ). 


\begin{tabular}{|c|c|c|c|c|c|c|c|c|c|c|c|c|}
\hline $\begin{array}{l}\text { Locati } \\
\text { on }\end{array}$ & Species & $\mathbf{n}$ & $\begin{array}{l}\mathrm{T} \\
\mathrm{L}\end{array}$ & $\begin{array}{c}\text { Lengt } \\
\text { h } \\
(\mathrm{cm})\end{array}$ & $\begin{array}{c}\text { Weight } \\
\text { (g) }\end{array}$ & $\begin{array}{l}\text { Sh } \\
\text { ore }\end{array}$ & $\begin{array}{c}\text { Habi } \\
\text { tat }\end{array}$ & $\begin{array}{l}\text { Fish } \\
\text { ing } \\
\text { dep } \\
\text { th } \\
\text { (m) }\end{array}$ & $\begin{array}{l}\delta^{15} N \\
(\%)\end{array}$ & $\begin{array}{l}\delta^{13} \mathrm{C} \\
(\% \circ)\end{array}$ & $\begin{array}{c}\text { Gro } \\
\text { up }\end{array}$ & $\begin{array}{c}\mathrm{Hg}(\mu \mathrm{g} \cdot \mathrm{g}- \\
1 \mathrm{dw})\end{array}$ \\
\hline \multirow{9}{*}{$\begin{array}{l}\text { Saint } \\
\text { Louis }\end{array}$} & Brotula barbata & 4 & 3. & $33.6 \pm$ & $287.8 \pm$ & Off $>>>>$ & $D$ & 33- & $11.14 \pm$ & $-16.99 \pm$ & 1 & $0.09 \pm$ \\
\hline & Drocura sarsaca & & 8 & 2.8 & 73.0 & U11 & U & 37 & 0.12 & 0.10 & $\perp$ & 0.01 \\
\hline & Merluccius & 5 & 4. & $36.4 \pm$ & $350.8 \pm$ & Off & R & 33- & $11.63 \pm$ & $-16.33 \pm$ & $1 \&$ & $0.22 \pm$ \\
\hline & senegalensis & כ & 5 & 1.7 & 55.3 & 011 & U & 37 & 0.59 & 0.36 & 2 & 0.11 \\
\hline & Pterothrissus & 5 & 3 & $25.6 \pm$ & $115.0 \pm$ & Off $>>>>$ & $D$ & 33- & $11.14 \pm$ & $-16.53 \pm$ & 1 & $0.08 \pm$ \\
\hline & belloci & & & 2.2 & 32.3 & 011 & D & 37 & 0.13 & 0.08 & 1 & 0.02 \\
\hline & Trichiurus lepturus & 5 & $\begin{array}{c}4 . \\
5\end{array}$ & $\begin{array}{c}70.7 \pm \\
4.7\end{array}$ & $\begin{array}{c}223.3 \pm \\
48.1\end{array}$ & Off & B & $\begin{array}{c}33- \\
37\end{array}$ & $\begin{array}{c}11.41 \pm \\
0.31\end{array}$ & $\begin{array}{c}-16.57 \pm \\
0.21\end{array}$ & 1 & $\begin{array}{c}0.06 \pm \\
0.01\end{array}$ \\
\hline & & 5 & 4. & $35.2 \pm$ & $661.1 \pm$ & Off & $B$ & $33-$ & $12.03 \pm$ & $-15.20 \pm$ & $1 \&$ & $0.18 \pm$ \\
\hline & & & & 5.1 & 268.0 & & & 37 & 0.51 & 0.55 & 2 & 0.04 \\
\hline \multirow{10}{*}{ Dakar } & Boons boons & 5 & 3 & $18.7 \pm$ & $63.8 \pm$ & $\ln$ & & $66-$ & $10.12 \pm$ & $-15.77 \pm$ & $1 \&$ & $0.14 \pm$ \\
\hline & & J & J & 1.6 & 22.2 & III & & 81 & 0.23 & 0.62 & 2 & 0.1 \\
\hline & Cara +2 & 1 & 3. & $19.9 \pm$ & $91.3 \pm$ & & & $66-$ & $11.53 \pm$ & $-15.42 \pm$ & & $0.05 \pm$ \\
\hline & & 4 & 6 & 1.4 & 13.1 & & & 81 & 0.17 & 0.43 & 2 & 0.01 \\
\hline & Dinleduc hellottii & 5 & 3. & $17.0 \pm$ & $77.9 \pm$ & $\ln$ & & $22-$ & $12.34 \pm$ & $-15.08 \pm$ & 2 & $0.34 \pm$ \\
\hline & Dipiocus detrotin & כ & 5 & 0.4 & 8.7 & & & 23 & 0.35 & 0.42 & 2 & 0.09 \\
\hline & Pseudupeneus & 5 & 3. & $21.1 \pm$ & $120.6 \pm$ & & $\mathrm{D}$ & $22-$ & $11.86 \pm$ & $-15.70 \pm$ & $1 \&$ & $0.21 \pm$ \\
\hline & prayensis & 5 & 2 & 1.8 & 32.5 & I & D & 23 & 0.36 & 0.44 & 2 & 0.07 \\
\hline & Scomber japonicus & 5 & $\begin{array}{l}3 . \\
4\end{array}$ & $\begin{array}{c}16.2 \pm \\
0.6\end{array}$ & $\begin{array}{c}32.9 \pm \\
5.2\end{array}$ & Off & $\mathrm{P}$ & $\begin{array}{l}66- \\
81\end{array}$ & $\begin{array}{c}8.01 \pm \\
0.28\end{array}$ & $\begin{array}{c}-16.70 \pm \\
0.34\end{array}$ & 1 & $\begin{array}{c}0.04 \pm \\
0.01\end{array}$ \\
\hline & Trachurus trecae & 5 & $\begin{array}{c}3 . \\
5\end{array}$ & $\begin{array}{c}21.8 \pm \\
0.4\end{array}$ & $\begin{array}{c}99.6 \pm \\
4.8\end{array}$ & In & B & $\begin{array}{l}22- \\
23\end{array}$ & $\begin{array}{c}10.92 \pm \\
0.18\end{array}$ & $\begin{array}{c}-16.42 \pm \\
0.26\end{array}$ & 1 & $\begin{array}{c}0.11 \pm \\
0.02\end{array}$ \\
\hline \multirow{17}{*}{$\begin{array}{c}\text { Salou } \\
\mathrm{m}\end{array}$} & Chaetodon hoefleri & 5 & $\begin{array}{c}3 . \\
5\end{array}$ & $\begin{array}{c}17.4 \pm \\
0.8\end{array}$ & $\begin{array}{c}147.6 \pm \\
17.2\end{array}$ & In & D & $\begin{array}{l}49- \\
81\end{array}$ & $\begin{array}{c}15.16 \pm \\
1.36\end{array}$ & $\begin{array}{c}-15.35 \pm \\
0.71\end{array}$ & $\begin{array}{c}1 \& \\
2\end{array}$ & $\begin{array}{c}0.14 \pm \\
0.08\end{array}$ \\
\hline & Chelidonichthys & 5 & 3. & $17.9 \pm$ & $123.8 \pm$ & $\ln$ & $\mathrm{R}$ & 49- & $10.88 \pm$ & $-16.96 \pm$ & & $0.37 \pm$ \\
\hline & gabonensis & 5 & 6 & 6.1 & 54.0 & $\mathrm{Im}$ & D & 81 & 0.23 & 0.35 & - & 0.14 \\
\hline & Dentex canariensis & 5 & 3. & $25.9 \pm$ & $259.8 \pm$ & In & $D$ & $49-$ & $12.32 \pm$ & $-16.54 \pm$ & 1 & $0.24 \pm$ \\
\hline & Derrex cumarterisis & J & 6 & 1.4 & 48.7 & & & 81 & 0.39 & 0.37 & & 0.14 \\
\hline & Dicologoglossa & 5 & 3. & $19.0 \pm$ & $87.2 \pm$ & $\ln$ & ח & 49- & $11.21 \pm$ & $-14.82 \pm$ & 2 & $0.42 \pm$ \\
\hline & hexophthalma & 2 & 4 & 1.0 & 11.2 & $\mathrm{In}$ & D & 81 & 0.14 & 0.14 & 2 & 0.28 \\
\hline & Plectorhinchus & 5 & 3. & $30.0 \pm$ & $376.2 \pm$ & In & $D$ & $49-$ & $12.65 \pm$ & $-15.30 \pm$ & 2 & $0.47 \pm$ \\
\hline & mediterraneus & כ & 5 & 1.2 & 53.2 & & & 81 & 0.22 & 0.09 & & 0.17 \\
\hline & Pseudupeneus & 5 & 3. & $21.4 \pm$ & $121.0 \pm$ & $\ln$ & D & $49-$ & $11.90 \pm$ & $-16.93 \pm$ & 1 & $0.43 \pm$ \\
\hline & prayensis & כ & 2 & 1.2 & 15.0 & IIII & D & 81 & 0.30 & 0.55 & $\perp$ & 0.36 \\
\hline & Sphoeroides & 4 & 3. & $12.6 \pm$ & $34.5 \pm$ & In & D & $49-$ & $11.34 \pm$ & $-15.57 \pm$ & $1 \&$ & $0.14 \pm$ \\
\hline & spengleri & & 2 & 0.4 & 2.1 & III & D & 81 & 1.16 & 0.45 & 2 & 0.06 \\
\hline & Trachurus trecae & 5 & 3. & $24.0 \pm$ & $137.6 \pm$ & $\ln$ & 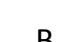 & 49- & $10.94 \pm$ & $-15.95 \pm$ & $1 \&$ & $0.09 \pm$ \\
\hline & macriarus crecae & J & 5 & 1.7 & 27.9 & III & $\mathrm{D}$ & 81 & 0.22 & 0.60 & 2 & 0.03 \\
\hline & Umbrina & 5 & 3. & $23.0 \pm$ & $147.8 \pm$ & Off & D & 49- & $11.48 \pm$ & $-15.99 \pm$ & $1 \&$ & $0.09 \pm$ \\
\hline & canariensis & & 4 & 1.0 & 16.3 & & & 81 & 0.27 & 0.21 & 2 & 0.05 \\
\hline \multirow{6}{*}{$\begin{array}{l}\text { Casam } \\
\text { ance }\end{array}$} & Brachydeuterus & 5 & 3 & $20.8 \pm$ & $127.2 \pm$ & $\ln$ & $B$ & $14-$ & $13.69 \pm$ & $-15.31 \pm$ & 2 & $0.35 \pm$ \\
\hline & auritus & & J & 0.4 & 5.0 & & & 15 & 0.30 & 0.15 & & 0.09 \\
\hline & Caranx rhonchus & 5 & 3. & $33.0 \pm$ & $334.4 \pm$ & In & B & 14- & $13.80 \pm$ & $-15.17 \pm$ & 2 & $0.58 \pm$ \\
\hline & 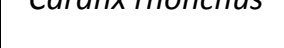 & J & 6 & 3.0 & 68.8 & III & $\mathrm{D}$ & 15 & 0.83 & 0.27 & 2 & 0.34 \\
\hline & Chloroscombrus & 1 & 3. & $20.1 \pm$ & $72.6 \pm$ & $\ln$ & $P$ & $17-$ & $13.51 \pm$ & $-16.31 \pm$ & $1 \&$ & $0.1 \pm$ \\
\hline & chrysurus & 0 & 5 & 0.9 & 8.0 & & & 18 & 0.45 & 0.61 & 2 & 0.03 \\
\hline
\end{tabular}




\begin{tabular}{|c|c|c|c|c|c|c|c|c|c|c|c|}
\hline $\begin{array}{l}\text { Galeoides } \\
\text { decadactylus }\end{array}$ & 5 & $\begin{array}{l}3 . \\
6\end{array}$ & $\begin{array}{c}17.6 \pm \\
1.3\end{array}$ & $\begin{array}{c}63.0 \pm \\
16.1\end{array}$ & In & D & $\begin{array}{l}14- \\
15\end{array}$ & $\begin{array}{c}13.51 \pm \\
0.20\end{array}$ & $\begin{array}{c}-15.65 \pm \\
0.23\end{array}$ & $\begin{array}{c}1 \& \\
2\end{array}$ & $0.08 \pm 0$ \\
\hline Selene dorsalis & 5 & $\begin{array}{r}4 . \\
1\end{array}$ & $\begin{array}{c}24.4 \pm \\
1.3\end{array}$ & $\begin{array}{c}170.0 \pm \\
22.7\end{array}$ & In & D & $\begin{array}{l}14- \\
15\end{array}$ & $\begin{array}{c}13.27 \pm \\
0.87\end{array}$ & $\begin{array}{c}-16.02 \pm \\
0.48\end{array}$ & $\begin{array}{c}1 \& \\
2\end{array}$ & $\begin{array}{c}0.23 \pm \\
0.05\end{array}$ \\
\hline $\begin{array}{c}\text { Sphyraena } \\
\text { guachancho }\end{array}$ & 5 & $\begin{array}{c}4 . \\
4\end{array}$ & $\begin{array}{c}34.4 \pm \\
3.4\end{array}$ & $\begin{array}{c}197.8 \pm \\
53.6\end{array}$ & In & $\mathrm{P}$ & $\begin{array}{l}14- \\
15\end{array}$ & $\begin{array}{c}13.78 \pm \\
0.84\end{array}$ & $\begin{array}{c}-15.77 \pm \\
0.32\end{array}$ & $\begin{array}{c}1 \& \\
2\end{array}$ & $\begin{array}{c}0.24 \pm \\
0.14\end{array}$ \\
\hline
\end{tabular}

Table 1: Summary (mean \pm standard deviation) of the different biological parameters measured on fish from different sampling sites. "TL" indicates trophic level based on Froese and Pauly, 2018. Based on the literature (see Materials and methods section),"Habitat" indicates water column distribution (D: Demersal, B: Benthodemersal, P: Pelagic), and "Shore" defines horizontal distribution of the species ("Off" includes bathydemersal and oceanodromous species while "In" includes coastal, brackish and estuarine species). "Group" is relative to k-means clustering of individuals based on ${ }^{13} \mathrm{C}$ values: " 1 " includes pelagic/offshore fish while " 2 " includes demersal/inshore individuals. 


\section{HIGHLIGHTS}

- THg, $\delta^{13} \mathrm{C}, \delta^{15} \mathrm{~N}$ were determined in 132 marine fish from a tropical coastal region

- Coastal and demersal species were more contaminated than oceanic and pelagic ones

- SIA suggest that $\mathrm{Hg}$ exposure derived from bottom feeding and/or in estuarine waters

- Conspecific fish fed on different coastal food webs and Hg increased with fish size

- Hg levels in fish from Senegal were not of concern for human consumption 


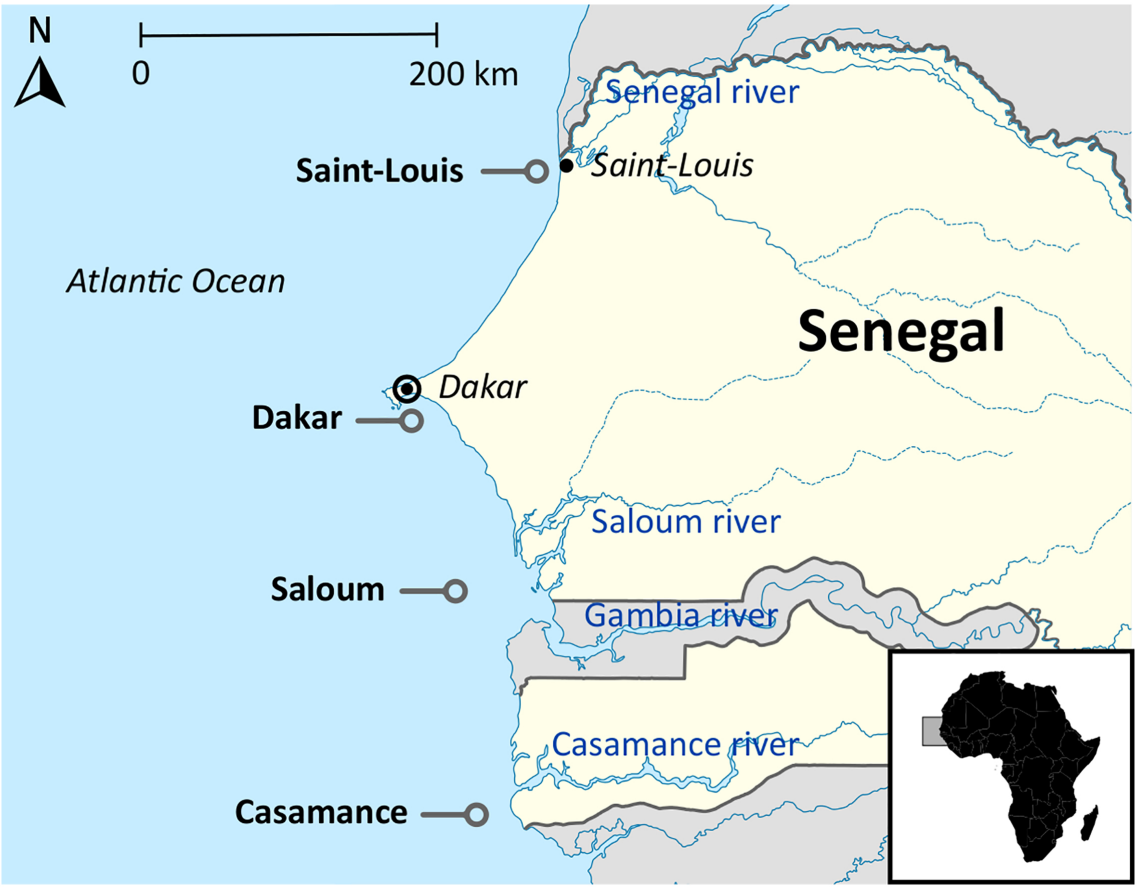

Figure 1 


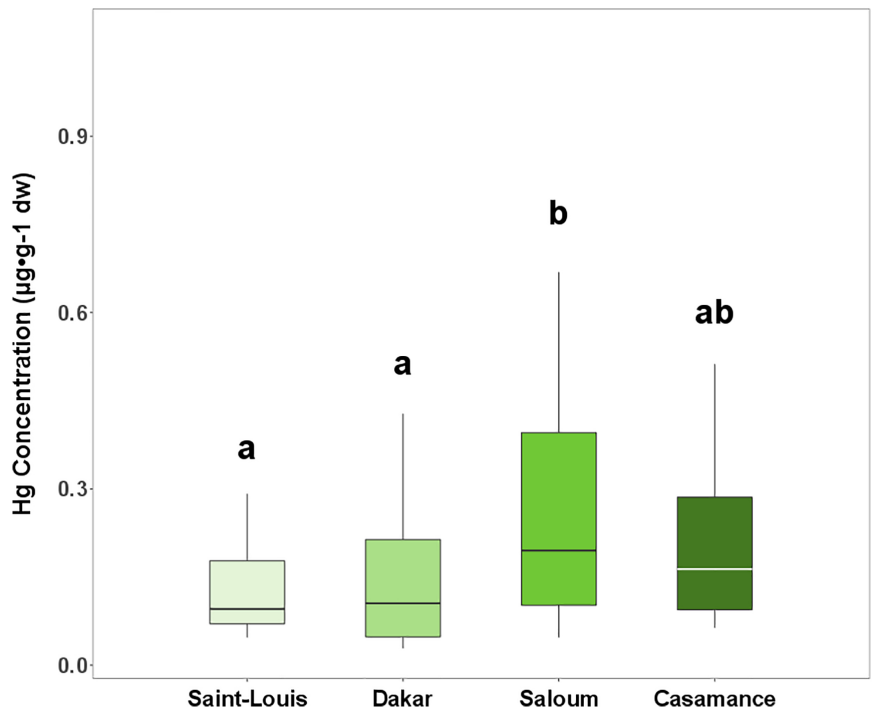

Figure 2 

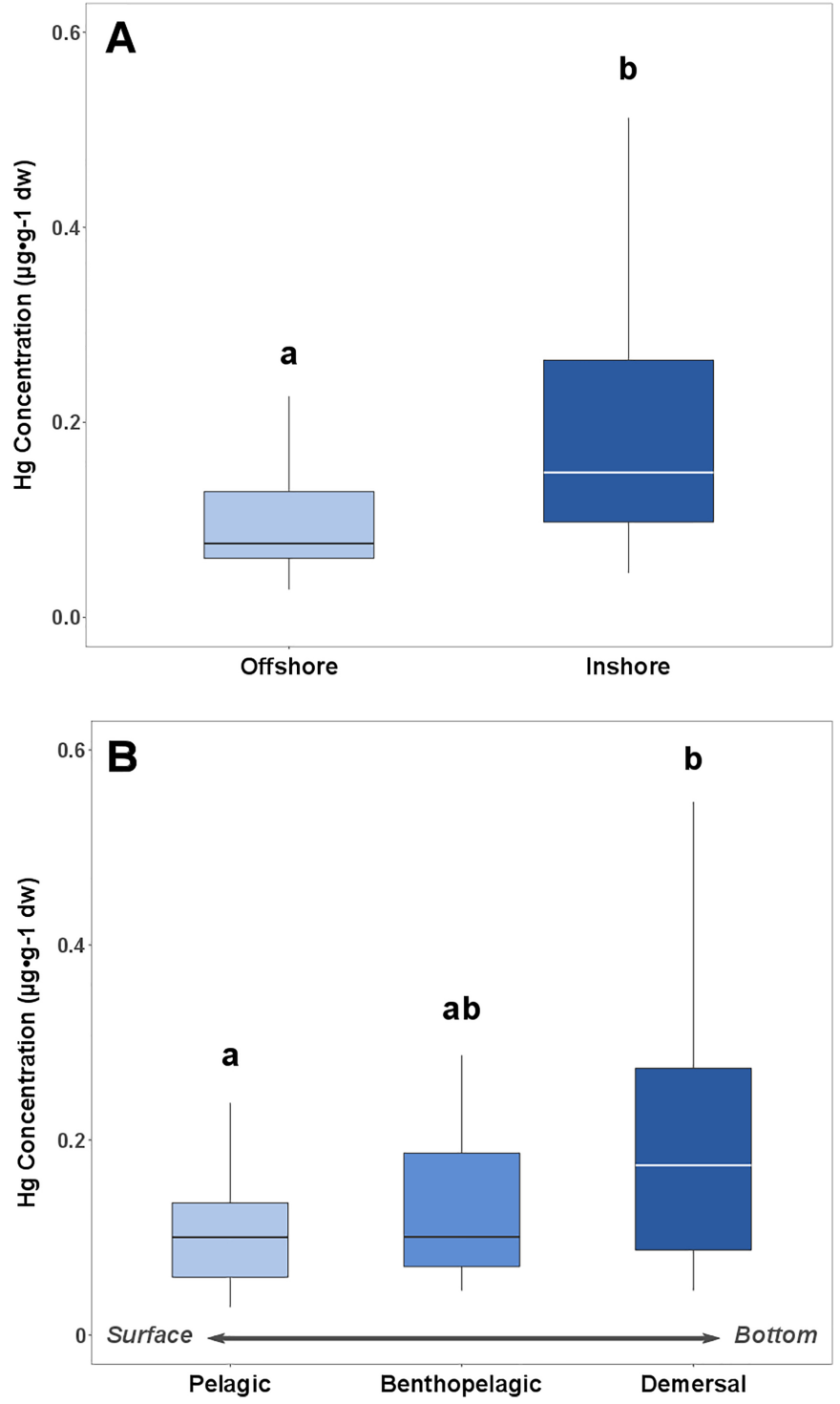

Figure 3 


\section{UV radiation}

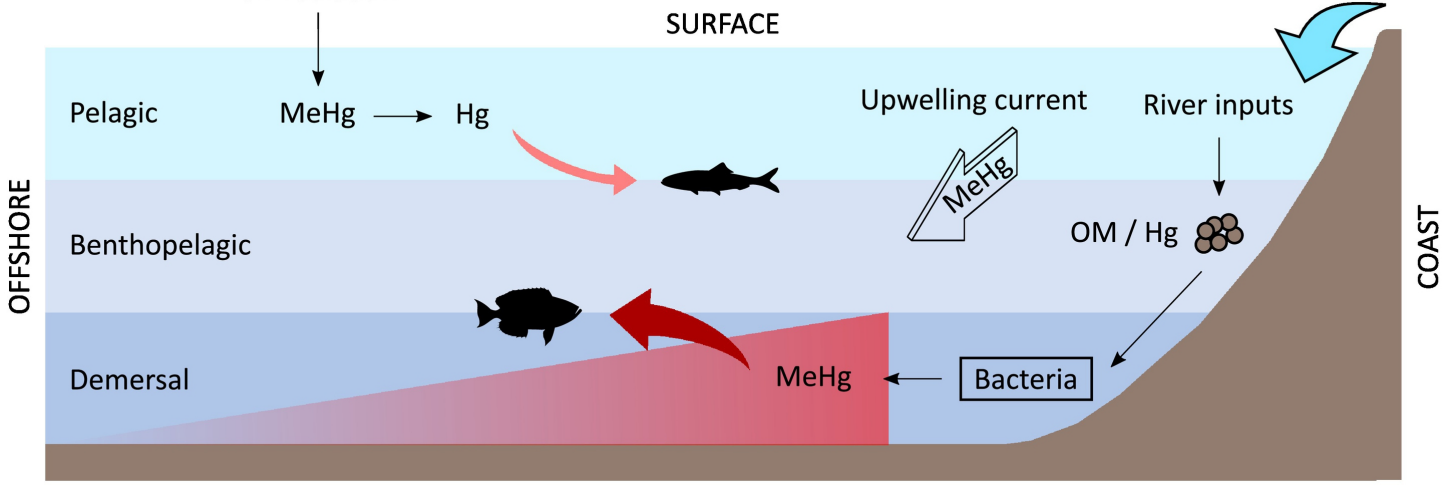

SEDIMENTS

Figure 4 

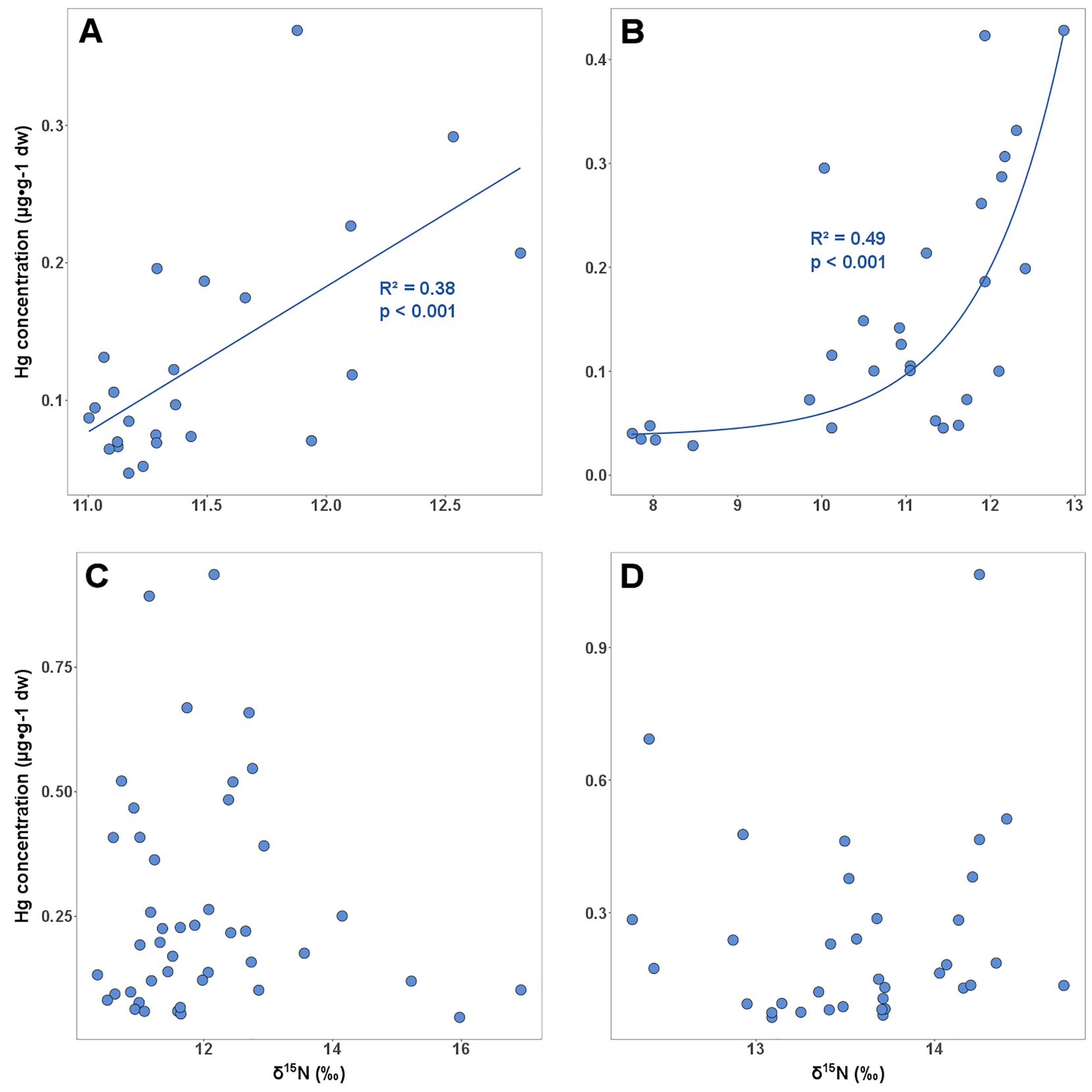

Figure 5 
A

1.0

.. Terrestrial inputs

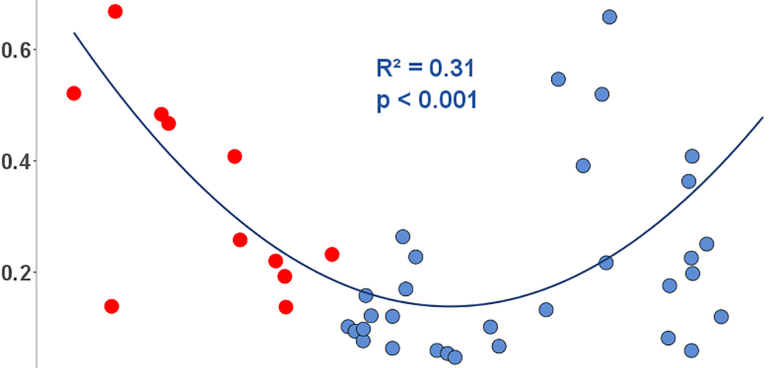

0.0
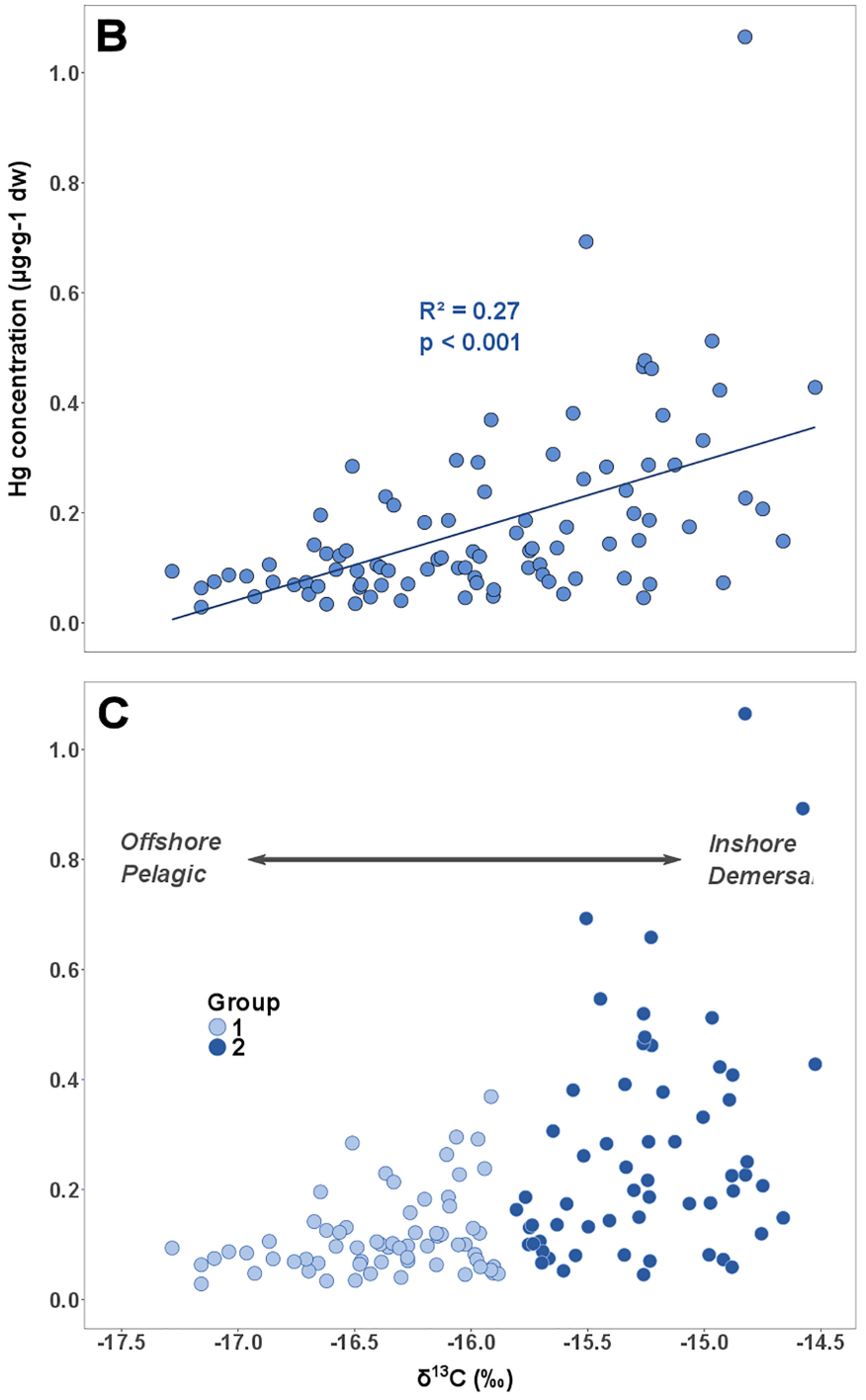

Figure 6 


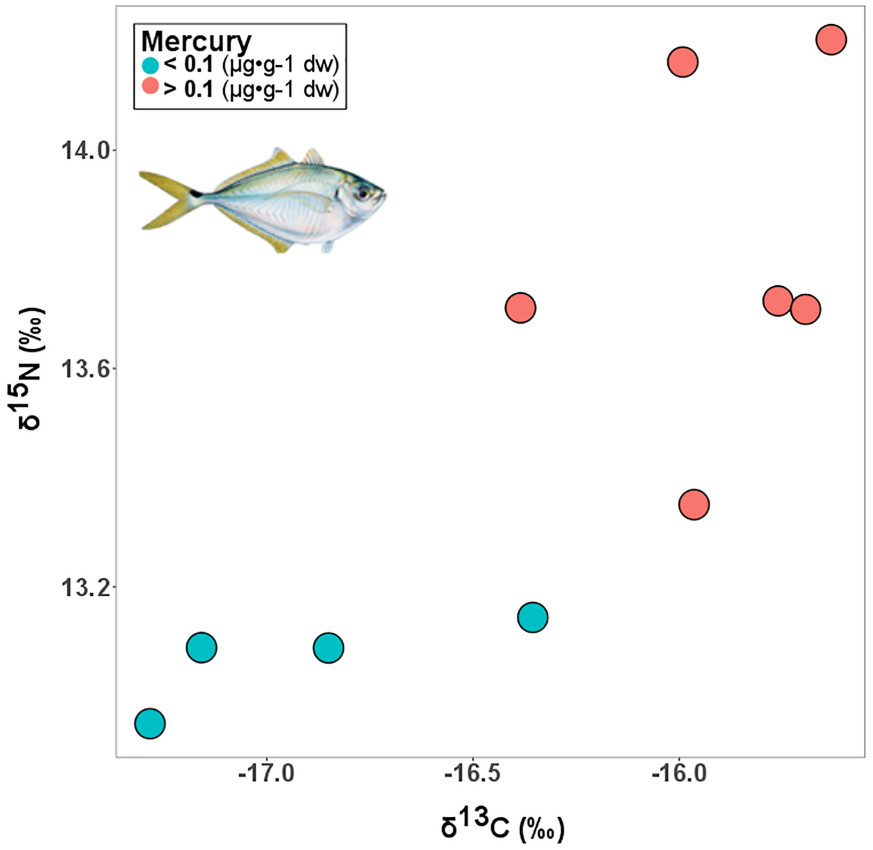

Figure 7 